\title{
Câmiu't-Tevârîh Yazmalarındaki Hz. Muhammed Konulu Minyatürlerin Bizans Resim Sanatındaki Kökenleri
}

\author{
Mustafa ÇETINASLAN
}

Doç. Dr., Selçuk Üniversitesi, Edebiyat Fakültesi, Sanat Tarihi, Konya, Türkiye mcetinaslan@gmail.com (Sorumlu Yazar/Corresponding Author)

\author{
Ali Can ÖZÇELIK
}

Arş. Gör., Selçuk Üniversitesi, Edebiyat Fakültesi, Sanat Tarihi, Konya, Türkiye ali.ozcelik@selcuk.edu.tr

\begin{tabular}{|c|c|}
\hline Makale Bilgileri & ÖZ \\
\hline $\begin{array}{l}\text { Makale Geçmişi } \\
\text { Geliş: } 17.06 .2021 \\
\text { Kabul: } 07.12 .2021 \\
\text { Yayın: } 31.12 .2021 \\
\text { Anahtar Kelimeler: } \\
\text { Câmiu’t-Tevârîh, } \\
\text { İslam Sanatı, } \\
\text { Hz. Muhammed, } \\
\text { Minyatür, } \\
\text { İkonografi. }\end{array}$ & $\begin{array}{l}\text { İlhanlı Hükümdarı Gazan Han'ın emriyle, vezir Reşîdüddîn Fazlullah-1 Hemedânî’nin gözetiminde hazırlanan Câmiu’t-Tevârîh, } \\
\text { bilinen en eski ve görece en tarafsız dünya tarihidir. Günümüze ikisi Arapça, ikisi de Farsça olmak üzere dört nüshası ulaşan } \\
\text { eser, 14. yüzyılın ilk yıllarında hazırlanmış ve resimlenmiştir. Çalışmaya konu olan Edinburgh Üniversitesi Kütüphanesi (Or. } \\
\text { Ms. 20) ve Khalili Koleksiyonunda (MSS 727) yer alan Arapça nüshalarda, Hz. Muhammed'in hayatını konu alan çeşitli } \\
\text { minyatürler de yer almaktadır. Çalışmanın amacı bu yazmalardaki "Hz. Muhammed'in Doğumu", "Peygamberliğin Tebliğ } \\
\text { Edilmesi/İlk Vahiy" ve "Beni Nadir Kabilesi Kuşatması" konulu minyatürlerin tarihi ve sanat özelliklerinin ortaya konulması } \\
\text { ile bu minyatürlerin Hrıstiyan/Bizans sanatındaki kökenlerinin tespit edilmesidir. Öncelikle söz konusu sahneler tanımlanacak } \\
\text { ardından tefsir, hadis ve tarihsel kaynaklar ş̧ı̆ı̆ında ikonografik ve ikonolojik çözümleme yöntemine göre sahnelerin oluşmasını } 1 \\
\text { sağlayan arka planın tespit edilmesine çalışlacaktır. Son olarak da Hrıstiyan/Bizans sanatındaki benzer örnekleriyle (Meryem } \\
\text { ve İsa'nın doğumu, Meryem'e müjde ve İsa Peygamberin Kudüs'e girişi sahneleri) ikonografik ve üslup karşıştırılmaları } \\
\text { yapılacaktır. Kanonik ve Apokrif İnciller'den beslenen Hrıstiyan/Bizans sanatının derin ikonografik altyapısına dayanan zengin } \\
\text { birikimi ile İslam tasvir sanatlarını kompozisyon ve figür alanlarında etkilediği açıtır. İslam sanatçısı henüz yeni olduğu } \\
\text { ikonografik resim alanındaki eksiklerini bu alandaki birikimi bulunan din ve kültürlerden almış ve kendi üslubuna uygun olarak } \\
\text { yorumlamıştır. Çalışmamız üç örnek resim üzerinden söz konusu etkileşiminin derinlik ve boyutlarını ortaya koymay1 } \\
\text { hedeflemektedir. }\end{array}$ \\
\hline
\end{tabular}

\section{The Origins of the Miniatures on the Theme of the Prophet Muhammad in the Jami' al-Tawarikh Manuscripts in Byzantine Painting}

\begin{tabular}{|c|c|}
\hline Article Info & ABSTRACT \\
\hline $\begin{array}{l}\text { Article History } \\
\text { Received: } 17.06 .2021 \\
\text { Accepted: } 07.12 .2021 \\
\text { Published: } 31.12 .2021 \\
\text { Keywords: } \\
\text { Jami` al-Tawarikh, } \\
\text { Islamic Art, } \\
\text { Muhammad, } \\
\text { Miniature, } \\
\text { Iconography. }\end{array}$ & $\begin{array}{l}\text { Câmiu't-Tevârîh, which was prepared under the supervision of the vizier Reşîudünin Fazlullah-1 Hemedânî, by the order of the } \\
\text { Ilkhanid Ruler Gazan Khan, is the oldest known, relatively reliable and impartial work in the history of the world. The } \\
\text { manuscript, of which four copies exist today, two in Arabic and two in Persian, was prepared and illustrated in the first years of } \\
\text { the 14th century. In the Arabic copies of the Edinburgh University Library (Or. Ms. 20) and the Khalili Collection (MSS 727), } \\
\text { which are the subject of the study, there are various miniatures on the life of the Prophet Muhammad. The aim of the study is to } \\
\text { reveal the historical and artistic features of the miniatures on the subject of "The Birth of the Prophet Muhammad", } \\
\text { "Declaration of Prophethood/The First Revelation", "The Siege of Beni Nadir Tribe" and to determine the origins of these } \\
\text { miniatures in Christian/Byzantine art. First of all, the scenes in question will be defined, and then, in the light of tafsir, hadith } \\
\text { and historical sources, it will be tried to determine the background that allows the formation of the scenes according to the } \\
\text { iconographic and iconological analysis method. Finally, iconographic and stylistic comparisons will be made with similar } \\
\text { examples in Christian/Byzantine art (The birth of Virgin Mary and Christ, The Annunciation, Entry to Jerusalem). It is clear } \\
\text { that the rich accumulation of Christian/Byzantine art, based on the deep iconographic infrastructure of the Canonical and } \\
\text { Apocrypha Gospels, influenced the Islamic depiction arts in the fields of composition and figure. The Islamic artist has taken } \\
\text { his deficiencies in the field of iconographic painting, which he is still new to, from the religions and cultures that have } \\
\text { knowledge in this field and has interpreted it in accordance with his own style. Our study aims to reveal the depth and } \\
\text { dimensions of the interaction in question through three sample pictures. }\end{array}$ \\
\hline
\end{tabular}

Atıf/Citation: Çetinaslan, Mustafa - Özçelik, Ali Can. "Câmiu’t-Tevârîh Yazmalarındaki Hz. Muhammed Konulu Minyatürlerin Bizans Resim Sanatındaki Kökenleri”. Selçuklu Medeniyeti Araştırmaları Dergisi (SEMA) 6 (Aralık 2021), 21-43. https://doi.org/10.47702/sema.2021.13 


\section{GİRIŞ}

14. yüzyılın başlarında İlhanlı (654-736/1256-1335) hükümdarı Gazan Han’ın (Hkm. 694703/1295-1304) emriyle vezir Reşîdüddîn Fazlullah-1 Hemedânî (645-718/1247-1318) tarafından kurulan Rab-1 Reşidi adlı mahallede üretilen en önemli eser, Câmiu’t-Tevârîh adlı resimli el yazmasıdır. İlk versiyonu üç, ikincisi dört ciltten oluşan ve bilinen ilk dünya tarihi olarak kabul edilen eserin ikinci cildi Peygamberler tarihi şeklinde düzenlenmiştir.

Tarihsel ve dini anlatımların minyatürlerle desteklendiği el yazmasında Hz. Muhammed (Sav)' in hayatından bölümler içeren dokuz kompozisyon yer almaktadır. Bu kompozisyonlar tasvirin hoş görülmediği İslam dininde Hz. Muhammed'in yüzünün de resmedilmesi sebebiyle hem üretildiği dönem hem de günümüz için önemli örneklerdendir. ${ }^{1}$ Dokuz kompozisyon arasında makalede ele alınan "Hz. Muhammed'in Doğumu", "Hz. Muhammed'e Peygamberliğin Teblĭg Edilmesi/Illk Vahiy" ve "Beni Nadir Kabilesi Kuşatması"nı konu alan sahneler, Bizans resim sanatı geleneğindeki bazı sahneler ile yakın benzerlik içerisindedir. ${ }^{2}$

Câmiu't-Tevârîh yazması edebi, tarihi ve sanat özelliklerinin ortaya konulmasına yönelik çeşitli çalışmalara konu olmuştur. Bununla birlikte bu yayında ele alındığ 1 şekliyle Hz. Muhammed'in hayatı ile ilgili sahnelerin İslamî kaynaklar ışığında değerlendirildiği ve söz konusu sahnelerin Bizans tasvir sanatındaki kökenlerinin tespit edilmesini amaçlayan bir araştırma bulunmamaktadır.

Çalışmada ikonografik inceleme yöntemi ${ }^{3}$ kullanılarak minyatürlerin doğal anlamına, ardından tefsir, hadis ve İslam tarihi ile ilgili kaynaklar ışığında da uzlaşmalı ve içsel anlamına değinilerek tasvirlerin İslamî alt yapısı ortaya konulmuştur. $\mathrm{Bu}$ yöntemle elde edilen bilgiler sayesinde de minyatürlerde yer alan sahneler, Hristiyan/Bizans sanatı içerisindeki benzer biçim özelliklerine sahip çeşitli örneklerle kıyaslanmış, böylece henüz gelişmekte olan İslam resim sanatı ve bu dönemde gelişmiş bir anlatım diline sahip Hristiyan resim sanatı arasındaki etkileşim ortaya konulmaya çalışılmıştır.

\section{Reşîdüddîn Fazlullah-ı Hemedânî ve Câmiu't-Tevârîh}

645/1247 yılında Hamadan'da bir Yahudi ailesinin ferdi olarak doğan Reşîdüddîn Fazlullah-1 Hemedânî, 1265-1282 yılları arasında İlhanlı Sultanı Abaga'nın şahsi doktorluğunu yapmış ve bu görevini Sultan Argun (Hkm. 983-690/1284-1291) ve Gazan Han döneminde de devam ettirmiştir.

\footnotetext{
${ }^{1}$ Hz. Muhammed'in en erken tarihli iki tasviri 13. yüzyılın ortalarında Konya'da nakkaş Muhammed İbni Abdülmü'min El-Hoyî tarafindan resimlenen Varka ve Gülşah Mesnevisi'nde yer almaktadır (TSMK, Hazine 841). Bir diğer tasvir ise Birûni'nin 1307-08 yıllarında resimlenen El-Âsâr'il-Bâkiye an'il-Kurûni'l-Hâliye isimli eserinde yer almaktadır (Edinburgh Üniversitesi Kütüphanesi, Or. Ms. 161, 20a).

${ }^{2}$ Çalışmada Hz. Muhammed (Sav)'in hayatını konu alan sahnelerden sadece Hristiyan/Bizans resim sanatında biçimsel benzerlikler bulunanlar ele alınmıştır. Benzerlik kurulamayan altı sahne ise çalışma dışında tutulmuştur. Bu sahneler Hz. Muhammed (Sav)'in Rahip Bahira ile karşılaşması (Or.Ms.20 f.43v), Hacer'ül Esved'in Kabe'deki yerine yerleştirilmesi (Or. Ms.20. f.45r), Miraç (Or.Ms.20 f.55r), Hz. Muhammed (Sav) ve Hz. Ebubekir'in Medine'ye hicreti (Or. Ms.20 f.57r), Hz. Muhammed (Sav)'in Bedir Savaşından önce ailesi ile görüşmesi (MSS 727 f.66a) ve Hz. Muhammed (Sav)'in Kaynuka kabilesine karşı Hz. Hamza ve Müslümanlara önderlik etmesi (MSS 727 f.67a) konularındadır.

${ }^{3}$ Erwin Panofsky’nin geliştirdiği İkonografik ve İkonolojik çözümleme yöntemi "Birincil veya doğal anlam”, "İkincil veya Uzlaşımsal Anlam" ve "İçsel Anlam” olmak üzere üç aşamadan oluşur. Doğal anlam olgusal ve ifadesel olmak üzere ikiye ayrılır. İncelenen eserde görülen biçimlerin ya da sanatsal motiflerin yalın hallerinin diğer nesnelerle arasındaki ilişki olgusal, bu biçimlerin altındaki anlam ise ifadesel anlamı oluşturur. Görünenin en yalın şekliyle aktarılması eserin ön-ikonolojisini meydana getirir. İkincil veya uzlaşımsal anlam ise doğal anlamda tespit edilen biçimlerin, eserde işlenilen tema ile bağlantı kurulmasıyla oluşur. Doğal anlamda biçimin sadece görünen hali bilinirken, burada biçim öykü ve alegorilerle bir anlam kazanarak imgeye dönüşür. Son olarak yapıtın içeriğinin dönemin koşulları ve sanatçının kişiliği gibi etkenlerle yorumlanmasıyla çıkan ikonografik sentezden de içsel anlam ortaya çıkar (Panofsky, 2012, 28-30)
} 
Başarılarından dolayı Gazan Han döneminde 697/1298 yılında vezirliğe yükseltilerek bu görevini 718/1318 y1lındaki ölümüne kadar sürdürmüştür (Jahn, 1964, 228; Jahn, 1966, 227-236).

697/1298 y1lında Reşîdüddîn Fazlullah-1 Hemedânî’nin vezirliğe yükseltilmesinden sonra Gazan Han, Tebriz yakınlarında Rab-1 Reşidi adlı bir mahalle kurdurulmasını emretmiştir. Kayıtlara göre mahallede yirmi dört kervansaray, bin beş yüz dükkân ve otuz bin konutun yanında hamam, darphane, boya ve kâğıt atölyeleri gibi bilim ve sanat faaliyetleri için gerekli ihtiyaçları karşılayacak birimlerin de yapıldığı bilinmektedir (Özgüdenli, 2002, 109). Mahalleye Hindistan, Çin, Mısır ve Şam'dan elli doktor getirtilmiş ve bir şifahane kurulmuştur. Bu doktorlar şifacıların sokağ denilen bir bölgeye yerleştirilmiş ve diğer ülkelerden gelen sanayiciler ve zanaatkârlar için de ayrı bir sokak kurulmuştur. Bilimin ön plana çıkarılmasını savunan Gazan Han dünyanın çeşitli yerlerindeki bilim adamlarını Rab-1 Reşidi'ye davet ederek, üretimi teşvik için burs ve çeşitli olanaklar sağlamıştır. Ayrıca, İslam ülkelerinden getirilen 1000 kadar öğrenci de devlet himayesi altında şehre yerleştirilmiştir (Wilber - Minovi, 1938, 247-249).

Mahalle kurulduktan sonra Gazan Han'ın emri ile hazırlanan Câmiu't-Tevârîh adlı eser, tarafsız ve modern anlamda ilk dünya tarihi olarak kabul edilmektedir (Şeşen, 1993, 132). Câmiu'tTevârîh, Gazan Han tarafindan sadece Moğol tarihi olarak düşünülmüştür. Ancak sonradan esere dünya tarihi ve bir coğrafya kitabı da eklenmiştir. Gazan Han döneminde bir kısmı bitirilen eser, Sultan Olcaytu (Hkm. 703-717/1304-1317) döneminde de yazılmaya devam edilmiştir. Bir Moğol, iki Çinli, birkaç İranlı, bir Budist rahip ve bir Hristiyan papazdan oluşan komite tarafından hazırlanan eserde, her milletin tarihi kendi bakış açısına göre tarafsız bir şekilde yazılmıştır (İnal, 1976, 55). Bunların dışında eserde Moğolların ve Türklerin ortaya çıkışı hakkındaki efsanelerden de söz edilmektedir (Çelik, 2016, 32).

Orijinalinin bazı bölümleri Farsça ve Moğolca olarak yazılan ve daha sonra kısmen Arapçaya çevrilen iki versiyonu olan eserin 704-706/1306-1307 y1llarında tamamlanan ilk versiyonu üç cilt, 709/1310'da tamamlanan ikinci versiyonu ise dört ciltten oluşur. Târih-i Gâzani olarak adlandırılan ve Gazan Han'a ithaf edilen birinci cildin (Şeşen, 1993, 132) ilk bölümü Moğol ve Türk hükümdarları, ikinci bölümü ise Cengiz Han'dan Sultan Olcaytu'nun tahta geçmesine kadar olan dönemi ele alır (Çelik, 2016, 33).

İki bölümden meydana gelen ikinci cildin ilk bölümünde, Sultan Olcaytu döneminin devamı anlatılır. Kendi içinde iki kısma ayrılan ikinci bölümde önce peygamberlerin ve halifelerin kısa bir tarihiyle birlikte, dünyadaki milletlerin ayrıntılı tarihçesi, ardından Olcaytu'nun hayatının devamı ele alınır. Üçüncü ciltte ise coğrafi tanımlamalar ve çeşitli yol güzergâhlarına yer verilmiştir (Çelik, 2016, $33)$.

Gazan Han ve Olcaytu dönemleri bizzat Vezir Reşidüddin tarafından yazılmış, diğer bölümlerse onun planına uygun şekilde yazdırılmıştır. Moğol tarihini, Moğolların İlhanlı Sarayındaki temsilcisi Chig-sang, Çin tarihini Li Tachi Maksun, Avrupa tarihini de Tebriz'de bulunan Hristiyan rahipler yazmıştır (Şeşen, 1993, 133). Eser muhtemelen Abdullah b. Ali el-Kâşânî ve Pulad ÇingSang'ın da (Bolad Ch'eng-Hsiang) bulunduğu pek çok kimsenin yardımıyla oluşturulmuştur. Gerektiği zaman resmi belgeler de kullanılmış ve bunların bazıları eserde olduğu gibi belirtilmiştir (Özgüdenli, 2011, 56).

Günümüze ulaşan dört Camiu't-Tevârîh yazmasından Topkapı Sarayı'nda olan ikisi (Hazine 1653-1654) (Aga-Oglu, 1934, 183-199; İnal, 1963, 163-175; İnal, 1975, 108-143; Ghiasian, 2018, 399-425) Farsça, Edinburgh Üniversitesi Kütüphanesi ve Khalili Koleksiyonundaki iki nüsha ise Arapça olarak yazılmıştır (İnal, 1976, 56). 714/1314-1315 yıllarında Arapça yazılan iki nüsha 
Camiu’t-Tevârîh'in günümüze ulaşan ${ }^{4}$ en eski tarihli kopyalarıdır (Blair, 2017, 2). Yazma İran'daki Moğol döneminin çağdaş resim üslubunu ortaya koymasının yanı sıra Uzak Doğu-Çin etkileri de taşımaktadır (Gray, 1954, 65).

Edinburgh Üniversitesi'ndeki nesih hatla yazılmış, 45,09x33,56 cm ölçülerinde ve yetmiş minyatür içeren nüsha, Reşîdüddîn Fazlullah-1 Hemedânî gözetiminde Tebriz'de hazırlanmıştır. Sonrasında Babürlülerin eline geçmesiyle birlikte Hindistan'a taşınan yazma/yazmaların, 1700'lü yılların ortalarında ikiye bölündüğ̈ ve iki kısmın da İngilizler tarafından satın alındığı düşünülmektedir. Edinburgh'daki nüsha Doğu Hindistan Şirketinden Albay John Baillie tarafından satın alınarak 1876 yılında Edinburgh Üniversitesine bağışlanmıştır. Royal Asiatic Society’e (Kraliyet Asya Cemiyeti) verilen nüsha ise daha sonra Khalili Koleksiyonuna geçmiştir. ${ }^{5}$

Khalili Koleksiyonundaki nüsha 43,5x30,0 $\mathrm{cm}$ ölçülerinde olup, altmış yapraktan oluşmaktadır. Nesih hatla yazılan yazmanın 11a no'lu sayfasında Timurlu Hükümdarı Şah Ruh'un mührü olması sebebiyle ona ait olduğu ileri sürülmektedir. ${ }^{6}$ Kompozisyon düzeni, surat tipleri, Uzakdoğu kökenli manzaralar ve motifler ve çizgi üslubuyla yapılmış minyatürler her iki nüshada da aynı karakteri gösterir (İnal, 1976, 60). İki Arapça nüshanın aynı olup olmadığına dair farklı görüşler mevcuttur. Blair boyut, format, sayfa düzeni, kenar boşlukları ve başlıklar arasındaki benzerliklere dayanarak iki nüshanın aynı kişinin gözetiminde kopyalandığını söyler (Blair, 2017, 2). Güner İnal da iki farklı koleksiyonda yer alan nüshaların ikisinde de "Yunus Peygamberin balığın karnından çıkmasının" tasvir edilmesi sebebiyle aynı yazma olmadığını savunmaktadır (İnal, 1976, 58).

\section{Câmiu't-Tevârîh'te Hz. Muhammed ile İlgili Sahneler}

\section{0), $f .42 r)$}

2.1. “Hz. Muhammed'in Doğumu” Sahnesi (Edinburgh Üniversitesi Kütüphanesi (Or. Ms.

Sayfanın alt kısmında yatay dikdörtgen bir çerçeve içerisinde ele alınan minyatür 27,5x11,0 cm ölçülerindedir (Resim 1). Sahnenin hemen üzerindeki kırmızı mürekkeple verilen "Nebi Aleyhissâlatü Vesselâm'ın doğumu” başlıklı bölümde, Hz. Muhammed (Sav)'in Fil Olayının yaşandığ1 y1lda 12 Rebîülevvel pazartesi günü doğduğu belirtilmektedir. Hz. Muhammed (Sav)'in anne-babas1 ve dedesi ile ilgili bilgilerin verildiği metinde doğum olayının nerede ve nasıl gerçekleştiği ile ilgili herhangi bir bilgi bulunmamaktadır.

Minyatürde konunun ön plana çıkarılması amacıyla arka planda az sayıda dekoratif unsura yer verilmiştir. Sahnenin ortasında sonradan yazıldığı anlaşılan Farsça notta "Velâdet-i hümâyûn pad-şâh-ı kâinat Aleyhisselam" yazmaktadır.

\footnotetext{
${ }^{4}$ Vezir Reşidüddin'in Sultan Olcaytu’yu zehirlediği iddiası ile Han Abû Said tarafindan idam ettirilmesinden sonra Rab-1 Reşidi ve burada üretilen eserler tahrip edilmiştir. Birçok nüsha halinde üretilen Camiu’t-Tevârîh yazmasının günümüzde tam bir nüshasının olmamasının en önemli sebebi bu tahrip süreci olmuştur (Özgüdenli, 2008, 20).

5 Edinburgh Üniversitesi, "Jāmi' al-tawārīkh (Compendium of Chronicles by Rashid al-Din), 714 A.H. (1314 C.E.)" (Erişim 7 Haziran 2021).

${ }^{6}$ Khalili Collection, “Jāmi` al-tawārīkh MSS 727”, (Erişim 7 Haziran 2021).
} 


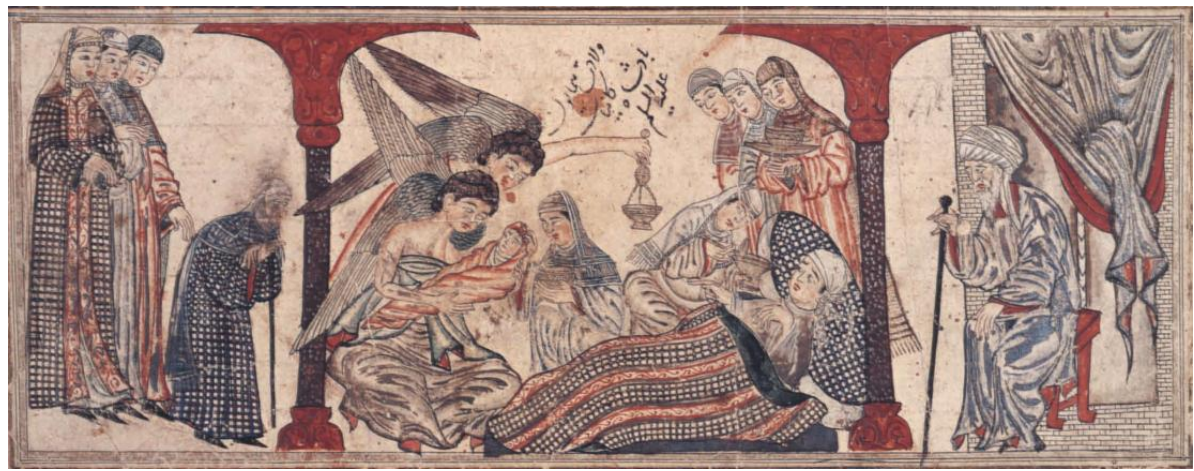

Resim 1. Hz. Muhammed'in Doğumu (Edinburgh Üniversitesi Kütüphanesi-Or.Ms.20, f.42r)

Düz bir zemin üzerinde çizgisel üslupta tasvir edilen doğum sahnesi, iki sütunla üç bölüme ayrılmış bir mekânda tasvir edilmiştir. Kaide, başlık ve köşelikleri üzerinde palmet ve kıvrımdalların işlendiği sütunların gövdelerinde benekli süslemelere yer verilmiştir. Sütunlar ve minyatürün sağında bulunan perdeyle örtülmüş giriş açıklığı olayın geçtiği yerin kapalı bir mekân olduğunu vurgulamaktadır. Ayrıca sütunlar kapalı bir mekân algısı oluşturmanın yanı sıra kompozisyonun merkezinde gerçekleşen doğuma odaklanılmasını sağlamaktadır.

Üç bölüme ayrılan sahnenin merkezinde doğum olayı aktarılmaktadır. Bu bölümde başında beyaz tülbent bulunan ve henüz doğum yaptığı anlaşılan bir kadın başını yastığa dayamış vaziyette uzanmaktadır. Kadının yaslandığı yastık ve üzerindeki örtü aynı kumaştan yapılmış olup, örtü üzerinde yastıkta olmayan rumî ve kıvrım dallı şeritlere yer verilmiştir. Kadının ayakucunda arka arkaya duran iki melek ve mavi elbiseli bir kadın figürü görülmektedir. Meleklerden öndeki bağdaş kurarak turuncu bir kumaşa sarılı bebeği kucaklarken; arkadaki melek ise baş1 eğik bir şekilde bebeğe bakmakta ve bir koluyla da doğum yapan kadına doğru uzattığı buhurdanlığı tutmaktadır. Meleklerin önünde duran mavi elbiseli kadın bir kâse tutmakta ve meleğin kucağında tuttuğu bebekle ilgilenmektedir. Doğum yapan kadının başucunda ise dört kadın figürü yer alır. Bu kadınlardan ilki elinde bir kâse ve kaşıkla kadına doğru eğilmiş ve kadına bir şeyler yedirmeye çalışmaktadır. Diğer üç figür ise yan yana dizilmiş şekilde ayakta durmakta ve bebeğe doğru bakmaktadırlar. Bu kadınlardan ilkinin elinde bir tepsi içerisinde yine bir kâse yer almaktadır.

Merkezin solundaki bölümdeyse ayakta duran uzun boylu, başları örtülü üç kadın yer almaktadır. Hemen önlerindeyse yaşlı ve hafifçe kambur bir kadın bastonuna dayanmış şekilde durmaktır.

Sahnenin sağ tarafında düğümlenmiş bir örtüyle kapatılabilen giriş açıklı̆ğ önünde başında beyaz sarığı ve uzun elbisesiyle, siyah renkli asasına dayanarak kırmızı bir taburenin üzerinde oturan yaşlı bir erkek figürü yer almaktadır.

Kuran-1 Kerim'de Hz. Muhammed'in doğum anından bahseden bir ayet bulunmamaktadır. Ancak Hz. Muhammed'in doğumuyla gerçekleşen mucizeler hakkında yazılmış pek çok kaynak vardır. İncelediğimiz minyatürde doğumun gerçekleştiği anın hemen sonrası ele alınmıştır. Bu konuyu ele alan en önemli kaynaklar Süleyman Çelebi'nin Vesîletü'n-Necât (811/1409) ve İmam Kastalâni'nin El-Mevahibü'l Ledüniyye (899/1494) isimli eserleridir. 
Doğum anından ayrıntılı olarak bahseden Vesîletü'n-Necât'ta ${ }^{7}$ evinde yalnız olan Hz. Âmine'ye Hz. Muhammed'in doğacağı müjdesini veren üç huri görünmüştür ${ }^{8}$. Doğumdan önceyse susayan Hz. Âmine'nin vücudu verilen şerbeti içmesiyle nurla kaplanmış ve sonrasında gelen beyaz bir kuşun sırtını sıvazlaması sonrasında da Hz. Muhammed doğmuştur. ${ }^{9}$ Doğumdan sonra kendine gelen Hz. Âmine bebeğini ak yünlü bir kumaşa sarılı vaziyette görmüştür. Hz. Peygamberin doğumuyla onun yüzünü görmek için yedi kat gök ehlinden melekler ve ellerinde nurdan tabaklarla cennetten gönderilen huriler gelmişlerdir (Süleyman Çelebi, 1992, 85-86).

El-Mevahibü'l Ledüniyye'de anlatılana göre Hz. Muhammed'in doğumundan önce dedesi Abdülmuttalib'in Kâbe'yi tavaf etmeye gitmesiyle Hz. Âmine evde yalnız kalmıştır. Şiddetli bir ses yüzünden korkmuş olan Hz. Âmine'nin yanına beyaz bir kuş gelerek kanadıyla sırtını sıvazlamış ve Hz. Âmine sakinleşmiştir. Yanına baktığı zaman ak kâse içerisinde sunulan şerbeti görüp içen Hz. Âmine'yi bir nurun sarmasıyla Hz. Muhammed dünyaya gelmiştir. Doğumun ardından ise etrafında her birinin boyu hurma ağacı gibi olan Abdümenâ $\mathrm{f}^{10}$ kızlarına benzeyen kadınlar çevresini sarmıştır (İmam-1 Kastalâni, 1996, 37-38).

Yukarıda tanımlamasını yaptığımız kompozisyonun merkezindeki doğum yapan kadın Hz. Âmine, meleğin kucağında tuttuğu bebek ise Hz. Muhammed'dir. Hz. Âmine'nin yanındaki iki kadın figüründen birisi sol taraftaki meleğin kucağında tuttuğu Hz. Muhammed ile ilgilenirken, diğer figür ise bir kâse içerisinde elindeki kaşıkla Hz. Âmine’ye şerbet içirmektedir.

Vesiletü'n-Necat'ta geçen ifadeye göre doğumdan sonra kendine gelen Hz. Âmine, çocuğu Hz. Muhammed'i ak yünlü bir kumaşa sarılı vaziyette görür. Ancak burada nakkaş beyaz yerine turuncu renkli bir örtü resmetmiştir. Vesiletü'n Necat'ta geçen bir diğer ifade de ise Hz. Peygamberi cennetten görmeye gelen, ellerinde nurdan tabaklar taşıyan hurilerden bahsedilir. Tasvirde sadece en öndeki kadının elinde tabak görülse de buradaki kadınlar bir figür grubu olarak değerlendirildiğinde cennetten gelen hurileri temsil ettikleri anlaşılır. Ayrıca yukarıdaki paragrafta bahsedilen iki önemli figür grubundaki herkesin Hz. Muhammed'e bakmalarının sebebi metinde de aktarıldığı üzere meleklerin ve cennetten gelen hurilerin hepsinin $\mathrm{Hz}$. Muhammed'in yüzünü görmesinden kaynaklanmaktadır. Buradaki uzun boylu kadınlar İmam Kastalâni'nin de belirttiği gibi Hz. Âmine'nin doğumdan sonra boylarını hurma ağacına benzettiği Abd-i Menaf kızlarıdır.

\section{2. “Hz. Muhammed'e Peygamberliğin Tebliğ Edilmesi/İlk Vahiy” Sahnesi (Edinburgh Üniversitesi Kütüphanesi (Or. Ms. 20), f.45r)}

Sayfanın alt kısmında, dört bir taraftan yazı ile kuşatılmış yatay dikdörtgen bir çerçeve içerisinde ele alınan minyatür 17,0x12,6 cm ölçülerindedir (Resim 2). Kırmızı mürekkeple yazılan

\footnotetext{
71997 yılında Prof. Dr. Necla Pekolcay tarafindan çevrilen Vesiletü'n-Necat adlı eserde Hz. Muhammed'in doğum anından 202-217 no'lu beyitler arasında bahsedilmektedir. 203 no'lu beyitte ise gerçekleşen olayların Hz. Âmine tarafından direkt olarak aktarıldığından söz edilmektedir (Süleyman Çelebi, 1992).

${ }^{8}$ Mevlid'in farklı yazmalardan derlenmiş bir nüshasında 68-70 numaralı beyitlerde Hz. Amine'ye görünen üç hurinin Asiye, Meryem ve güzel bir huri olduğu belirtilmektedir (Süleyman Çelebi, 1980, 97).

${ }^{9}$ Muhammad Hamidullah'da doğum sırasında Hz. Âmine'nin acı çekmediğinden söz etmektedir (Hamidullah, 2003, 40).

${ }^{10} \mathrm{~Hz}$. Muhammed'in baba tarafindan üçüncü dedesi asıl adı Mugire olan Abdümenâf b. Kusay’dır. Annesi Hubba'nın onu Mekke'deki büyük putlardan Menâf'a adadığı için Abdümenâf adını almıştır (Fayda, 1988, 287). Abdümenaf b. Kusay’ın oğlu, Hz. Muhammed'in büyük dedesi olan Hâşim b. Abdümenâf, Beni Hâşim koluna adını veren kişidir. Hz. Muhammed'in dedesi Abdülmuttalip ile birlikte dört oğlu ve beş kızı vardır (Sarıçam, 1997, 406). Hz. Muhammed'in anne tarafından dedesi ise Vehb b. Abdümenâf’tır (Topaloğlu, 1991, 63). Abdümenâf soyundan gelen Abdülmuttalib'in altı kızı olduğu bilinmektedir (Adıgüzel, 2018, 83). Bu sebeple metinde geçen Abdümenâf kızları ifadesi kesin olmamakla birlikte Hz. Muhammed'in halalarını vurgulamak için kullanılmış olmalıdır.
} 
“Mustafa Aleyhisselâm'a vahyin başlaması ve onun davete (tebliğe) başlaması" başlıklı bölümde, Hz. Peygamberin 40 yaşında iken Ramazan ayının bir pazartesi günü Hira Dağı'nda Cebrail (As) ile karşılaşması anlatılmaktadır. Hz. Muhammed (Sav) ve Cebrail (As) arasında geçen bu karşılaşmadan sonra Hz. Peygamberin önce eşi Hz. Hatice'ye ve onun tavsiyesi üzerine Varaka bin Nevfel'e danıştığı da metinde aktarılmaktadır. Ayrıca Alak Suresi'nin ilk beş ayeti ile olayın Ramazan Ayında gerçekleşmesinin delili olarak Bakara ve Kadir surelerinden ayetlere verilmiştir. Resim-metin ilişkisi bağlamında sadece olayın geçtiği Hira Dağı belirtilmektedir.

Sahne kayalık bir alanda yer alan iki figürden ibarettir. Kontur çizgilerinden içe doğru açılan renk tonlamalarıyla kayaların plastik etkisi güçlendirilmiştir. Buradaki dağlık manzara aynı yazmanın f.22r numaralı sayfasında bulunan Meryem'e müjde sahnesi ile benzerlik göstermektedir. İki sahnede de figürler, Uzak Doğu üslubunda tasvir edilen dağlık bir manzaranın önündedir (İnal, 1976, 57). Gray, Câmiu't-Tevarih'in yazımında yer alan kurulda Çinlilerin olması sebebiyle ağaç ve dağ tasvirlerinin Çin resimlerindeki manzara geleneğini önemli ölçüde yansıttığını ileri sürmektedir (Gray, 1977, 25).

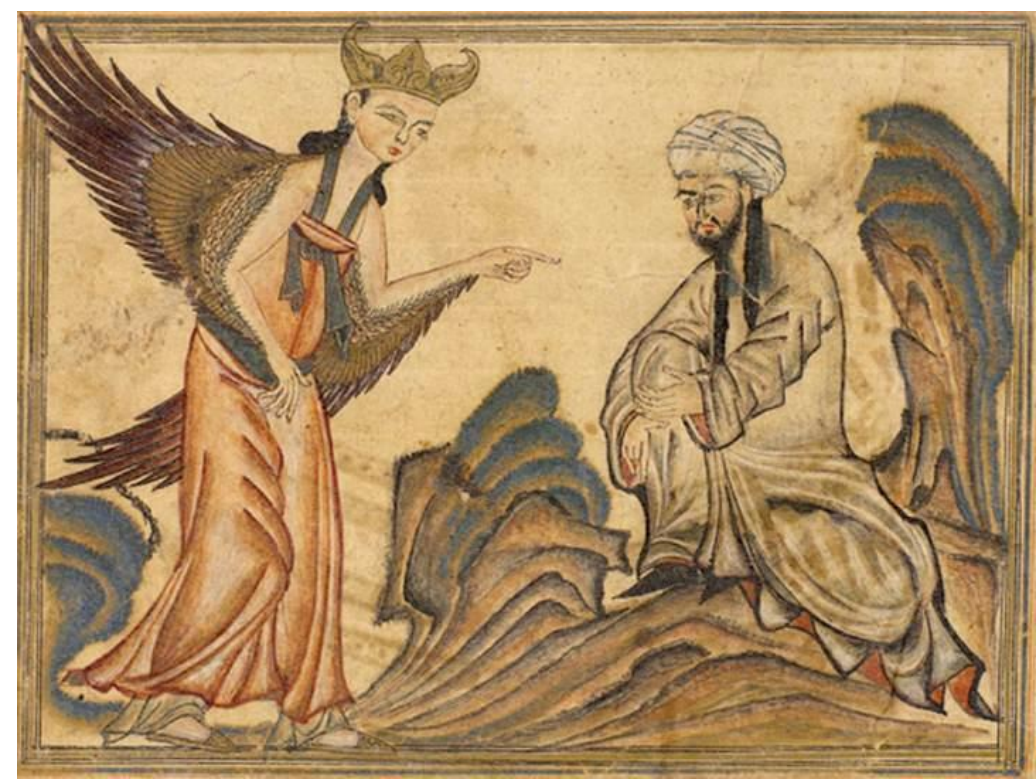

Resim 2. Hz. Muhammed'e Peygamberliğin Tebliğ Edilişi (Edinburgh Üniversitesi Kütüphanesi-Or.Ms.20, f.45r)

Kompozisyonun sağ tarafında bir kayanın üzerinde 3/4 cepheden verilmiş, iki eli dizinde birleşmiş şekilde oturan sakallı bir erkek figürü görülmektedir. Üzerinde dışı beyaz içi kırmızı renkli bir cüppe ve başında beyaz bir sarık vardır. Selçuklu tipinde tasvir edilen bu figürün saçları örgülüdür ve yüzünün iki yanından sarkmaktadır. Sol taraftaysa düz bir zemin üzerinde duran, siyah renkli askıların taşıdığ turuncu bir elbise ve ayaklarında terlikle tasvir edilen, kanatları kollarının arkasından uzayan bir melek figürü vardır. Meleğin başında sarı renkli, palmet ve rumî motifleriyle süslenmiş üç dilimli bir taç vardır.

Sahnede dört büyük melekten biri olan Cebrail, Hz. Muhammed'e doğru eğilmiş ve sol eli ile onu işaret eder vaziyette resmedilmiştir. Yukarıda ele alınan kompozisyonda Kuran'1 Kerim'in Alak Suresinin 1-5 numaralı ayetlerinde (el-Alak 96/1-5) bahsedilen Hz. Muhammed'e ilk vahiy ile peygamberliğin tebliğ edilmesi olayı tasvir edilmiştir. Ancak bu ayetler olayın nerede ve nasıl geçtiği hakkında bilgi vermek yerine "Oku!" emri ve sonrasında gelen vahiylerden söz etmektedir. Olayın nerede ve nasıl geçtiği hakkındaki bilgiyi sahih kabul edilen hadisler vasıtası ile öğrenebilmekteyiz. 
Hz. Ayşe’nin aktardığı hadis-i şerifte “...Hira mağarasına çekilip orada, ailesine dönmeksizin birkaç gece tek başına kalıp, tahannüs'de bulunuyordu. Bu maksatla yanına azık alıyor, azı̆̆ı tükenince Hz. Hatice radıyallahu anha'ya dönüyor, yine aynı şekilde azık alıp tekrar gidiyordu. Bu hal, kendisine Hira mağarasında Hak gelinceye kadar devam etti. Bir gün ona melek gelip: "Oku!" dedi". "if ifadeleri geçmektedir. Bu hadise göre Hz. Muhammed'e Cebrail tarafindan getirilen ilk vahiy olan "Oku!" emri ve peygamberliğin bildirilmesi Hira mağarasında gerçekleşmiştir. Hira Mağarası, Mekke'nin kuzeydoğusunda yer alan Cebelinur adıyla da bilinen Hira Dağı'nda bulunmaktadır (Günel, 1998, 121). Bu bilgiler doğrultusunda arka plandaki dağlık manzara Hira Dağı, soldaki melek figürü Cebrail ve sağdaki erkek figürü de kendisine ilk kez vahiy gelen $\mathrm{Hz}$. Muhammed'dir.

\section{3. “Beni Nadir Kabilesi Kuşatması” Sahnesi (Khalili Koleksiyonu (MSS. 727), f.8a)}

Sayfanın üst kısmında yatay dikdörtgen bir çerçeve içerisinde ele alınan minyatür 25,5x12,0 cm ölçülerindedir (Resim 3). Metinde 15 gün süren bir kuşatmanın ardından Beni Nadir kabilesinin teslim alınışı anlatılmaktadır. Peygamberin ağzından anlatılan olayda kabile mensuplarının Müslümanlarla yapılan anlaşmayı bozmaları ve sözlerini tutmamaları sebebiyle kuşatmanın yapıldığı belirtilmektedir. Teslim olanların evlerini, silahlarını ve mallarını bırakmak koşuluyla şehri terk etmelerine izin verildiği ve ganimetlerin Müslümanlar tarafından paylaşıldığının anlatıldığı metinde, resimdeki kompozisyonla ilgili herhangi bir ifade söz konusu değildir.

Dikdörtgen çerçeve içerisinde çizgisel üslupta işlenen sahnenin sol tarafinda bir kale/kent ve tepede güneş yer almaktadır. Sahnenin bütününde herhangi bir doğa unsuruna yer verilmemiştir. Kompozisyonun solunda yokuşla çıkılan, yarım daire kemerli ve çift kanatlı ahşap kapı ile belirtilen bir giriş görülmektedir. Gerek üç dilimli tepelikle sonlanan giriş açıklığın üzerinde gerekse sur üzerinde rumî ve kıvrım dallardan oluşan bir çerçeveye yer verilmiştir. Rampa şeklindeki çıkış ve yüksek bir burcun işlenmesi yapının bir kale olduğunu ortaya koymaktadır.

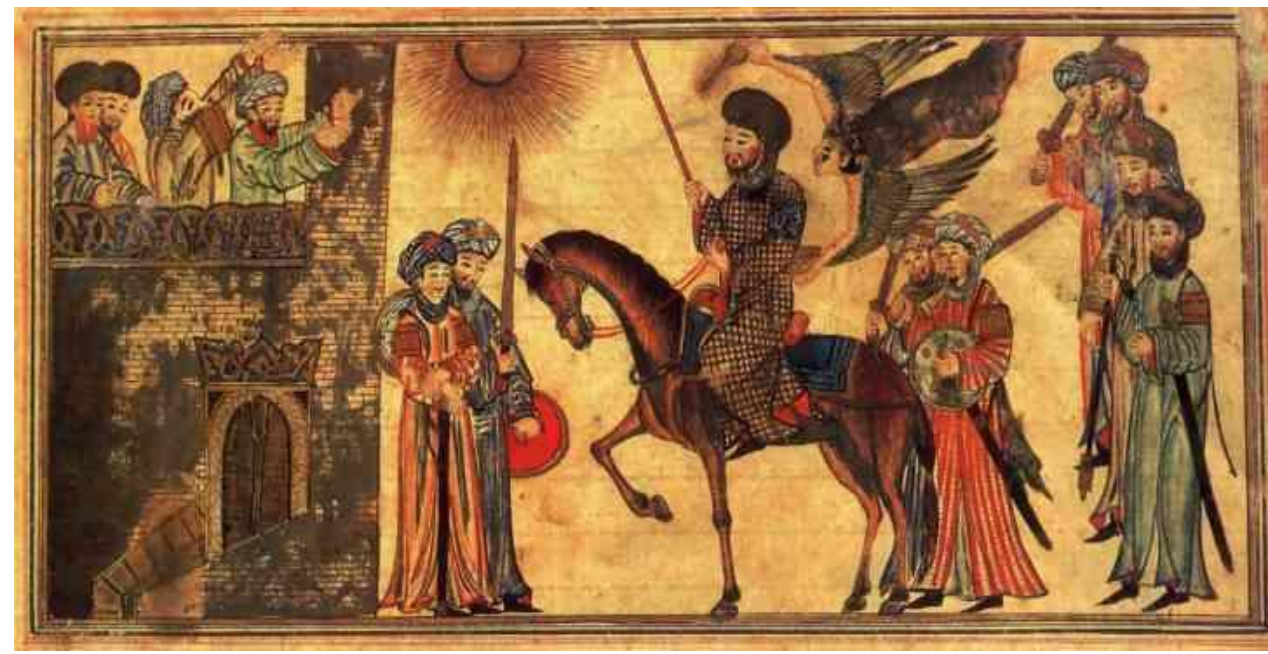

Resim 3: Hz. Muhammed'in Beni Nadir Kabilesini Kuşatması

(Khalili Collections - MSS 727, f.8a)

Kalenin hemen önünde yan yana tasvir edilmiş iki figür yer almaktadır. Bu figürlerden elleri önünde bağl1, turuncu bir elbise giyen ve iki kolunda tiraz/pazubent bulunan figür silahsız olup, sahnenin ortasında at üzerindeki figürü karşılar şekilde tasvir edilmiştir. Bu figürün hemen yanındaki mavi elbiseli figür ise sol elinde kalkan, sağ elinde yukarı doğru kaldırdığı bir kılıçla karşılama

${ }^{11}$ Buhari, Bed'ü'l-Vahy, Enbiya 21, Tefsir, Alâk Ta'bir 1; Müslim, İman 252, (160); Tirmizi, Menakıb 13, (3636). 
pozisyonundadır. Kalenin seğirdim yolundaysa dört insan figürü bulunmaktadır. Bu figürlerden sağdaki ilk ikisi merkezdeki figürü ve askerleri karşılar şekilde elleri açık biçimde verilmiştir.

At üzerinde erkek figürü sahnenin merkezinde yer almaktadır. Sağ ayağı kalkık ve iki arka ayağının gözükmesiyle hareket ediyormuş gibi görünen at aslında ideal duruş pozisyonunda sahibine itaat eder vaziyette durmaktadır. Ön ayağının kalkık olması atın harekete geçmek için sabırsızlandığı göstermektedir. Atın üzerindeki figür ise başı 3/4 cepheden Selçuklu figür tipinde tasvir edilmiştir. Figürün üzerine oturduğu eyerse bir soylu eyeri olup savaşmaya yönelik değil yolculuğa yöneliktir. Kaftan ve sol kolunda tirazla tasvir edilen figür, sol eliyle atın yularını, sağ eliyle de sancak ya da mızrak tutmaktadır. Atın üstünde ayakları bulut şeklinde biçimlendirilmiş insan gövdeli ve kanatlı bir melek figürü yer almaktadır. Melek üstteki eliyle bir şişe, alttaki eliyle de bir kâse tutmaktadır.

Kompozisyonun sağında ise ellerindeki silahlardan asker olduğu anlaşılan altı erkek figürü yerleştirilmiştir. $\mathrm{Bu}$ figürlerden ikisi atın arkasında olup merkezdeki figüre yaverlik ederken, sağ köşedeki ayakta duran askerler ise mavi, sarı ve kırmızı olmak üzere farklı renkte elbiseler giymiş olarak yan yana yerleştirilmişlerdir. Turuncu bir kıyafetle tasvir edilen yaverlerden öndeki, sol elinde kalkan ve sağ elinde kılıç tutmaktadır. Yanındaki yaverin vücudu öndeki tarafından kapatıldığı için sadece yüzü ve elinde tuttuğu kılıç belli olmaktadır. Sahnenin ön kısmında yer alan yaver ve arkasındaki dörtlü gruptaki ilk askerin sol kollarında tiraz bulunması, perdelenen diğer figürlerde de tiraz bulunduğunu düşündürmektedir.

Beni Nadir Kabilesi, MÖ 587'de Buhtunnasr ${ }^{12}$ ya da MS 70 y1lında Roma İmparatoru Titus'un Kudüs'ü işgal etmesiyle Beni Kurayza ve Beni Kaynuka ile Medine civarına yerleşen üç Yahudi kabilesinden biridir (Özkuyumcu, 2006, 275). Beni Nadir ve Beni Kurayza tarım ve hayvancıllk yaparken, Beni Kaynuka kabilesi ekonomik olarak daha avantajlı olan silah imalatı ve kuyumculukla uğraşıyordu. Beni Kaynuka kabilesi sayesinde üstün konuma gelen Yahudiler, Medine'de Arap kabileleri karşısında daha fazla çoğalmış ve utum/taş duvarlı yapı adı verilen kaleye benzeyen konaklar inşa etmişlerdir. ${ }^{13}$ 621-22 yıllarına gelindiğinde gerçekleşen Akabe Biatlar ${ }^{14}$ sonucunda ortam hicret için uygun hale gelmiş ve 622 yllında Mekkeli Müslümanlar Medine'ye Hicret etmişlerdir. Hicret sonrasında farklı dinlere mensup insanların bir arada yaşadığı şehirde düzenin sağlanması amacıyla Medine Vesikas ${ }^{15}$ adı verilen bir antlaşma imzalanmıştır (Bozkurt - Küçükaşçı, 2003, 306).

Vesika'nın imzalanmasından ve Bedir Savaşının gerçekleşmesinden sonra hem Beni Kaynuka kabilesinin sürgüne gönderilmesi hem de şair Kâ'b b. Eşref'in kışkırtıcı davranışlarından dolayı Hz. Peygamber'in tarafından ölüm emri verilmesi Yahudileri endişelendirmiştir. Bu sebeple Yahudilerle bir antlaşma yapılmış (Özkuyumcu, 2006, 275) ancak bu antlaşma bir süre sonra Beni Nadir kabilesi tarafından bozulmuştur. ${ }^{16}$

${ }^{12}$ Keldani hanedanının ilk kralı olan Nabopolassar'ın ilk oğlu ve Yeni Babil Krallığının kurucusudur. Yahuda kralı Yehoyakim'in Babil krallığına vergi ödemeyi reddetmesi üzerine Buhtunnasr MÖ 597 yılının Mart ayında Kudüs şehrini almıştır. Kudüs halkının MÖ 586 yılında tekrar isyan etmesi sonucunda ise şehri yakmış ve Süleyman Mabedini ise yıktırmıştır (Harman, 1992, 380).

${ }^{13}$ Beni Nadir Kabilesi ile ilgili olaylar için bk. Mustafa Asım Köksal, "İslâm Tarihi Hz. Muhammed (As.) ve İslamiyet”, (İstanbul: Şamil Yayınevi, 1981), 73-101

14 Hz. Peygamber tarafından, Medineli Evs ve Hazrec kabilelerine Akabe'de İslam'ın tebliğ edilmesi ve kabilelerin iman etmesi olayı (Önkal, 1989, 211).

15 İslam tarihindeki ilk anayasa olarak kabul edilen Medine Vesikası hakkında daha fazla bilgi için bk. Mustafa Özkan, "Medine Vesikası", TDV İslam Ansiklopedisi (31.01.2020).

16 Söz konusu antlaşmanın bozulması ile ilgili iki rivayet aktarılır: Bunlardan birisi Hz. Peygamber'in Amiroğullarından öldürülen iki kişinin diyeti için Beni Nadir ile antlaşma sağladıktan sonra Hz. Peygamber'e düzenlenen suikast girişimidir (Ebul Hasen Ali en-Nedvi, 1992, 95). Bir diğer rivayet ise Müslümanların Uhud 
Suikast girişiminin Cebrail tarafından Hz. Peygamber'e bildirilmesiyle Hz. Peygamber, Müslümanların Beni Nadir Kabilesi ile yapılacak olan savaşa hazırlanmalarını emretmiştir (Ebul Hasen Ali en-Nedvi, 1992, 95). Hz. Peygamber tarafindan Beni Nadir kabilesine şehri on gün içinde terk etmeleri için uyarı yapılmasına rağmen Hazrec kabilesinin reisi olan Abdullah b. Übey b. Selûl, Beni Nadir kabilesine uyarıyı dikkate almamalarını ve Müslümanlarla savaşmalarını söylemiş ve $\mathrm{Hz}$. Peygamber tarafından yapılan teklif reddedilmiştir (Koçyiğit, 1988, 140). 625 yılının Ağustos ayında Müslümanlar tarafından on beş gün kuşatılan şehir herhangi bir destek gelmeyince teslim olmuştur (elHaşr 59/1-24). Teslim şartları gereğince Beni Nadir Kabilesi mensupları silah dışındaki eşyalarını yanlarına alarak altı yüz deve yüküyle kuzey yönüne doğru yola koyularak şehirden ayrılmışlardır (Özkuyumcu, 2006, 275).

Yukarıdaki bilgilere göre kompozisyon değerlendirildiğinde merkezde yer alan at üzerindeki figür Hz. Muhammed'dir. Kuşatmadan önce bu olaya sebep olan suikast girişiminin Hz. Muhammed'e Cebrail tarafindan bildirildiğini göz önüne aldığımız zaman melek figürünün Cebrail olduğu anlaşılmaktadır. Sol tarafta savunma amaçlı yapılmış kaleye benzeyen mimari yapıda yukarıda sözü edilen kabileye ait altı utumdan biridir.

Kompozisyonun geneline bakıldığında iki ayrı kuvvetin savaş için konumlandığı izlenimi uyanmakla birlikte on beş günlük kuşatma sırasında herhangi bir mücadelenin geçtiğine dair bir bilgi bulunmamaktadır. Hem çekilme şartları hem de kale önündeki figürlerin duruş pozisyonu dikkate alındığında bu figürlerin Beni Nadir Kabilesinden olmaları mümkün görünmemektedir. Seğirdim yolu üzerindeki figürlerin jestleri de dikkate alındığında sahnenin şehrin Müslümanlar tarafindan teslim alındığg ve Hz. Muhammed'in şehre giriş anını gösterdiği anlaşılmaktadır.

\section{Değerlendirme ve Karşılaştırma}

Câmiu't-Tevârîh yazmalarında Hz. Muhammed'in hayatından olayların konu edinildiği minyatürlerin yukarıda İslamî ikonografisi açıklanmış ve tanımı yapılmıştır. Bu bölümde ise elde ettiğimiz bilgiler 1şığında minyatürlerin Hristiyan ikonografisindeki kökenleri ve Bizans sanat1 ile benzerlikleri ortaya konulacaktır.

İlk olarak ele aldığımız "Hz. Muhammed'in Doğumu” sahnesinin Bizans sanatındaki konu ve biçim açısından en yakın benzerleri Meryem ve İsa 'nın Doğumu sahneleridir. Meryem'in doğumu ile ilgili bilgiler Kanonik İnciller'de değil; Apokrif kabul edilen Meryem'in Doğumu İncili, Sahte Matta İncili ve Apokrif Yakup İncili’nde ${ }^{17}$ anlatılmaktadır (Yörük, 2016, 228).

Meryem'in Doğumu İncili'nde Ioakhim ve Anna'nın kızı olan Meryem'in Davut'un soyundan geldiği ve Kudüs'te yetiştirildiği yazmaktadır (Meryem'in Doğum İncili, 1). ${ }^{18}$ Ioakhim'in çöle çekilip yanında olmamasına üzülen Anna (Sahte Matta İncili 2: 3), Tanrı'ya bir evlat vermesi için dua eder (Yakup İncili 2: 1-3). Anna'ya bir melek tarafından “Anna, Anna, Rab senin duanı işitti. Hamile kalacaksın ve doğuracaksın, senin soyun bütün dünyada anılacak" (Yakup İncili 4: 1, Sahte Matta

Savaşını (23 Mart 625) kaybetmesinden dolayı Yahudilerin fikir değiştirip antlaşmayı bozması ve Kâ'b b. Eşref'in de Ebû Süfyân ile gizlice kurduğu ittifakın ortaya çıkmasıdır (el-Haşr 59/1-24).

${ }^{17}$ Hristiyanlığın ilk zamanlarında yazılan İncilin pek çok tercümesi ve nüshası mevcuttur. Ama bunların en eskisi Bodmer 5 Papirüsü olarak bilinen ve 3-4. yüzyıla tarihlenen yazmadır. Burada kullanılan isim Meryem'in Doğumu, Yakub'un Vahyi'dir. Daha sonraki yazılan Yunanca el yazmalarında ise "Hikâye, Tarih, Haber" kelimeleriyle birlikte Yakub'un ismi de yazılıdır. Yazmanın proto-incil (ilk incil) olarak isimlendirilmesi diğer incillerden önce yazıldığı sonucunu vermektedir. Ayrıca incilin Hz. İsa'nın çocukluğu ve gençliğini anlatması sebebiyle de diğer incillerden önce yazılmış olduğunu ileri sürenler mevcuttur. (Sarıķığlu, 2009, 123; Michaelis, 1958, 63).

${ }^{18}$ Work of God, "The Gospel Of The Nativity Of Mary”, (Erişim 21 Şubat 2020). 
İncili 2: 5) diye duasının kabul edildiği bildirildikten sonra Meryem'in de Kutsal Ruh'la dolacağ1 aktarılarak İsa'nın geleceği müjdelenmiştir (Meryem'in Doğumu İncili 3: 5).

Meryem'in doğum sahneleri Ioakhim'in zenginliğini gösteren bir yatak odasında gerçekleşir. $\mathrm{Bu}$ sahnelerde Anna yatağa uzanmış bir şekilde arka plandayken, Meryem'e ilk banyosunu yaptıran ebeler ön plandadır (Tükel - Yüzgüller Arsal, 2014, 91). Tasvirlerde yaşlı olarak tasvir edilen Anna ve Ioakhim'in yanı sıra, Anna'ya hizmet eden kadınlar da betimlenmiştir (Pekak - Durmuş, 2015, 177; Sach vd., 1988, 143).

İsa'nın doğumu sahneleri Bizans'ın erken dönemlerinden (4-7. yüzyıl) itibaren s1klıkla tasvir edilen sahnelerdendir (Coşkuner, 2010, 104). İsa'nın doğumu Kanonik İnciller'den sadece Luka'da ele alınmaktadır. Roma yönetimince gerçekleştirilen nüfus sayımı sebebiyle herkesin kendi atalarının şehrine gitmesi gerektiği için Yusuf da nişanlısı Meryem'le Beytlehem'e doğru yola çıkar. Yolculuk esnasında Meryem, İsa'yı doğurur ve handa yer olmadığı için onu kundağa sararak yemliğe yatırır (Luka 2: 6-7). Luka İncilinde İsa'nın doğumu handa gerçekleşirken, apokrif olan Yakup İncili ve Sahte Matta İncili’nde ise mağarada gerçekleşir (Yakup İncili; Tischendorf Metni: 1, (Sarıkçığlu, 2009, 134) Sahte Matta İncili 13: 2).

İsa'nın doğumu sahneleri bazen Luka'nın anlatımına göre bir handa, bazen de apokrif metinlere bağlı olarak mağarada tasvir edilir. Apokrif metinlerdeki anlatım Bizans ve Doğu ikonografisi örneklerini oluşturmaktadır. Ayrıca doğum sahnelerinin en önemli öğelerinden birini Apokrif Matta İncili'nde bahsedilen nefesleriyle yemliği isıtan öküz ve eşek figürleri oluşturmaktadır (Tükel - Yüzgüller Arsal, 2014, 99-100). 431 yılındaki Efes konsilinde Meryem'in Theotokos (Tanr1 Anas1) kabul edilmesiyle Meryem ve Yusuf, 6. yüzyıldan sonra da İsa'nın ilk banyosuyla ebe Mea ve Salome sahneye eklenmiştir (Coşkuner, 2010, 106-110). Bunların yanı sıra çobanlar, çobanlara müjde veren melekler ve yıldızdan çocuk İsa'ya doğru inen bir 1şık huzmesi de görülmektedir (Maguire, 2011, 40).

İsa'nın doğumu sahnelerinde genellikle kompozisyonun merkezinde İsa'yla birlikte yer alan Meryem, yemlik içerisinde bulunan çocuk İsa'yla yan yana uzanır bir şekilde tasvir edilir. Ayrıca Daphne Manastırı Kilisesi'ndeki ${ }^{19}$ mozaikte ve II. Basil'in Menologion'undaki (Vatican Library, Vat.Gr.1613, f.271) minyatürde olduğu gibi yemliğin yanında oturarak tasvir edildiği örnekler de vardır. Yusuf figürü ise genellikle bir kayanın üzerine bastonuna yaslanarak oturur şekilde tasvir edilir. Apokrif metinlerde geçtiği şekilde kompozisyonlarda yer edinen ebe figürleri bazı örneklerde İsa'y1 yıkarken, bazen de onunla ilgilenirken gösterilirler.

Meryem ve İsa'nın doğumu hakkındaki ikonografik altyapı ve doğumun Bizans sanatında nasıl işlendiğine dair bilgilere değindikten sonra değerlendirmeye ilk olarak olayın geçtiği mekânlardan başlanacaktır. Yazılı kaynaklara göre Hz. Muhammed'in doğumu ev ortamında gerçekleşmiştir. Meryem'in doğumunun da evde ya da mimari bir mekân önünde geçmesi sebebiyle mekân açısından bir benzerlik söz konusudur. Ancak burada mekânların benzerliğinin sebebi aşağıda ayrıntılı olarak bahsedileceği üzere figürlerin kompozisyonlar arası etkileşiminden ziyade yazılı kaynaklarda konu hakkında verilen bilgilerdir. İsa'nın doğumu sahneleri ise Kanonik ve Apokrif metinlerde bir birlik olmamasından dolayı han ve mağara olmak üzere iki ayrı yerde tasvir edilir.

Kompozisyonun ana öğesini oluşturan Hz. Âmine, Anna ve Meryem figürlerinin konumlarına baktığımızda Anna, Hz. Âmine gibi merkezde yer almaz. İncelediğimiz tüm örneklerde Meryem

\footnotetext{
${ }^{19}$ Yunanistan'da bulunan Atina ve Eleusis arasında kalan manastırın katholikonudur. İlk olarak 7. yüzyılda bazilikal planlı bir kilise olarak tasarlanan yapı tahrip olmuş, yerine 11. yüzyılda yapılan ve günümüze kadar ulaşan kilise yapılmıştır (Pantazis - Papathanassiou, 2005, 64).
} 
merkezde konumlandırılırken, Daphne Manastırı'ındaki örnek dışında Anna kompozisyonun să̆ tarafında yer almaktadır. Hosios Loukas Manastırı Kilisesi ${ }^{20}$ ve II. Basil'in Menologion'unda bulunan iki örnekte yemliğin başında oturarak resmedilen Meryem dışındaki anne figürleri, genellikle uzanır vaziyettedir. Ancak hiçbiri Hz. Âmine gibi tam olarak sırt üstü uzanmaz. Anna'nın belden yukarıs1 diğer figürlere göre biraz daha yukarıdadır. Ayrıca Anna, Santa Maria in Trastevere, ${ }^{21}$ Kariye Kilisesi, ${ }^{22}$ (Resim 4) II. Basil'in Menologion'u (Vat.Gr.1613, f.22) örneklerinde kolundan destek alarak uzanmaktadır.

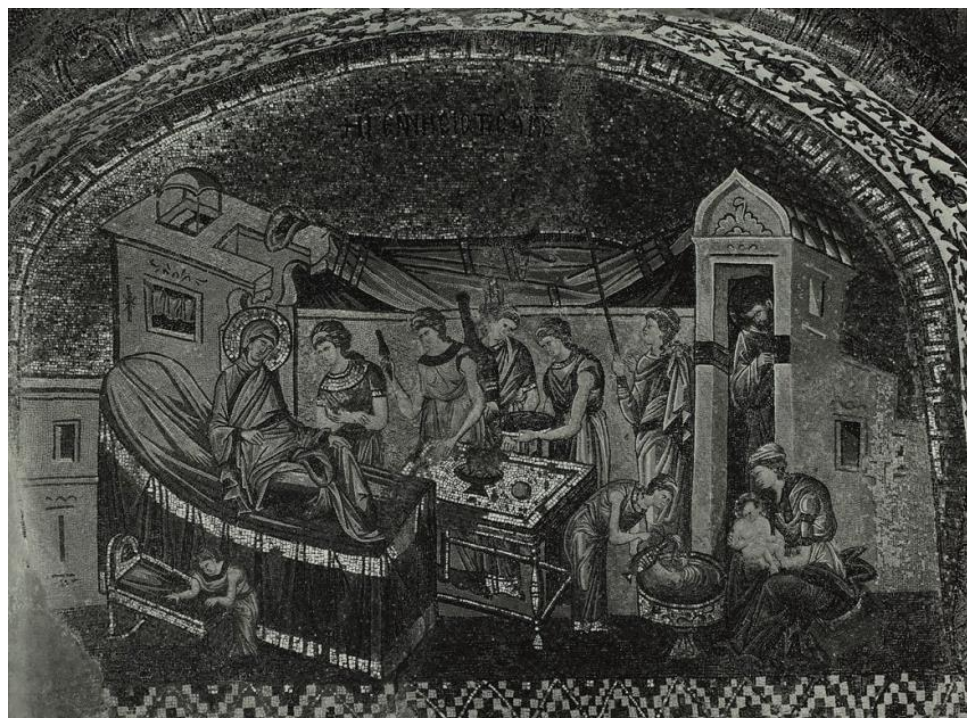

Resim 4. Meryem'in doğumu, Kariye Müzesi, 1315-1321 (Dumbarton Oaks)

Hz. Âmine'nin sağ arkasında, ellerinde nurdan yapılmış tabaklar olan cennetten gelen hurileri sembolize eden üç kadın figürü vardır. Bu figür grubunun benzerleri Meryem'in doğum sahnelerindeki ellerinde tabaklar tutan hizmetçiler olarak karşımıza çıkmaktadır. Hz. Muhammed'in doğum sahnesindeki kadınlar kutsallığ ${ }^{23}$, Meryem'in doğumu sırasındaki hizmetçiler ise Ioakhim'in zenginliğini göstermektedir. Bu huri/kadın grubunun varlığı yazılı kaynaklarda geçmekle birlikte, tasvire aktarılmaları ile açık bir etkileşimi de ortaya koymaktadırlar. İsa'nın doğumu sahnelerinde ise böyle bir huri/kadın grubu söz konusu değildir.

Hz. Âmine'nin solunda yer alan, onunla ilgilenen iki kadın ${ }^{24}$ ve birinin Hz. Muhammed'i tuttuğu iki melek figürü ile meleklerin arkasında yer alan yaşlı kadın Meryem'in ve İsa'nın ilk banyosunu yaptıran ebelerle/kadınlarla ilişkilidir. Yakup İncili’nde Meryem'e doğum yaptıran ebenin mağaradan çıktıktan sonra Salome’ye bir bakirenin doğum yaptığından söz ettiği anlatılmaktadır. Buna inanmayan Salome, Meryem'in bekâretini kontrol etmek isteyince eli yanarak vücudundan düştü. Bunun üzerine dua etmeye başlayan Salome'ye Tanrı "Elini çocuğa uzat ve onu okşa (kucağına al)" dedi ve Salome bunun üzerine İsa'yı kucağına aldı ve eli iyilești (Yakup İncili; Tischendorf Metni

\footnotetext{
${ }^{20}$ Yunanistan sınırları içerisinde yer alan 10. yüzyılda yapılmış manastır, St Lukas Stiriotis adındaki bir keşişe adanmıştır (Arletti vd., 2010, 798-799).

${ }^{21}$ Roma'nın en eski kiliselerinden biri olan yapı 3. yüzyılda inşa edilmiştir. Ancak günümüze ulaşan yapı, Papa II. Innocent tarafindan 12. yüzyılda yaptırılan kilisedir (Dixon, 1981, 30).

${ }^{22}$ İstanbul'un Edirnekapı semtinde yer alan Kariye Manastırının, İsa'ya adanmış kilisesidir. Pek çok değişim ve onarım geçirdiği bilinen yapı günümüzdeki halini Theodoros Metokhites'in yaptırdığı onarımlar sonucunda almıştır (Eyice, 2001, 24/495-496).

${ }^{23}$ Söz konusu figürlerin Asiye, Meryem ve huri olduğuna dair ifadeler kutsallık düşüncesini güçlendirmektedir (Süleyman Çelebi, 1980, 97).

${ }^{24}$ Pseudo-Matta İncili'nin on üçüncü bölümünde Salome'nin Zelome ile birlikte Yusuf'un bulduğu iki ebeden birisi olduğu belirtilmektedir (Pekak - Durmuş, 2015, 183).
} 
1-3). Sahnenin solunda yer alan Abd-i Menaf kızları ile Hz. Muhammed'i tutan melek arasında bastonuna dayanmış vaziyette bekleyen yaşlı kadının kimliği de bu bilgiler 1şı̆̆ında ortaya çıkmaktadır. İslam anlatımında herhangi bir yeri bulunmayan bu kadın tamamen Hristiyan anlatımından sahneye dâhil olmuş olan Ebe Salome olmalıdır.

Bizans sanatı içerisinde değerlendirmeye aldığımız doğum sahnelerinde İsa yemlik içerisinde olduğundan dolayı Meryem, İsa'yı kucağında tutmamaktadır. Ancak Niğde Andaval Eski Gümüşler Manastırı $^{25}$, Tokalı Kilise (Resim 5), Karanlık Kilise, (Resim 6) Sarnıç Kilise, Çarıklı Kilise ${ }^{26}$ ve Mavrucan Haç Kilisesi ${ }^{27}$ gibi Kapadokya bölgesinde yer alan örneklerde ilk banyo temasının yoğun olarak tercih edildiği de görülmektedir. Meryem'in doğum sahnelerinde ise doğum ve ilk banyo sahneleri birlikte tasvir edilmiştir. Her iki durumda da yeni doğmuş bebekle, anne yerine başkaları ilgilenmektedir. Yukarıda bahsedildiği gibi yeni doğmuş Hz. Muhammed de annesinin kucağında değil, kendisi ile ilgilenen iki melekten birinin kucağındadır.

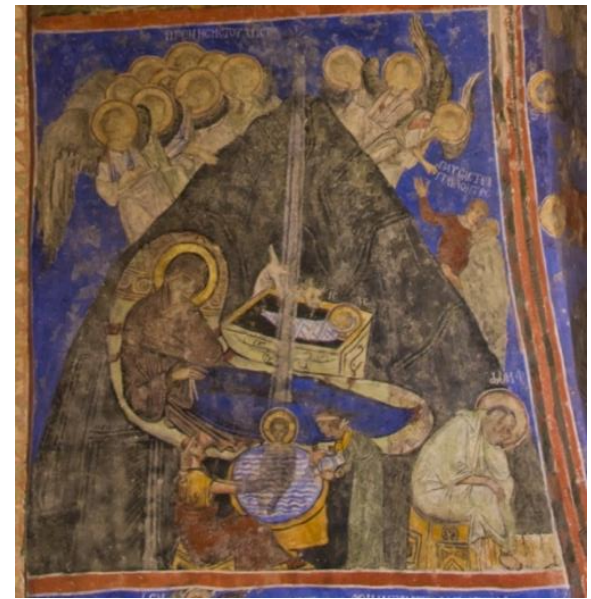

Resim 5. İsa'nın Doğumu - Tokalı Kilise(Antoine Taveneaux)

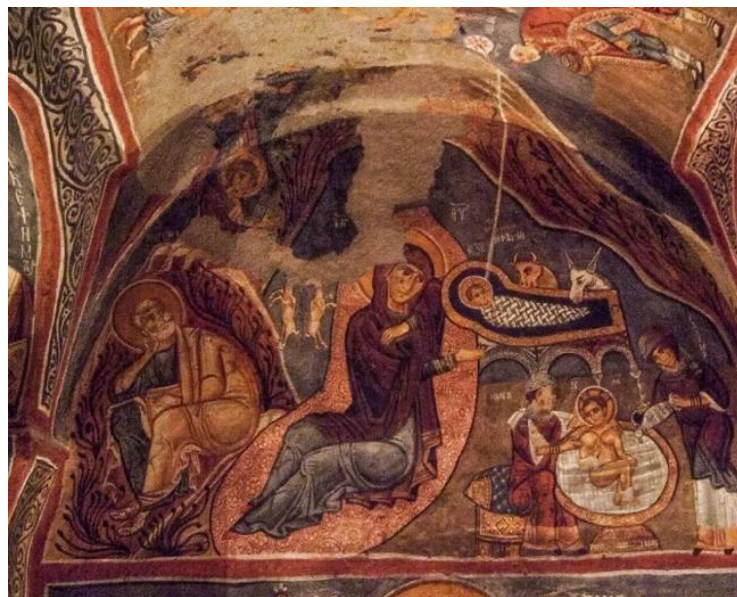

Resim 6. İsa'nın Doğumu -Karanlık Kilise(Jose Huwaidi)

İncelediğimiz doğum sahneleri içerisinde figürler arasındaki en yakın benzerlik Abdülmuttalib ve Yusuf karakterlerinde görülmektedir. Fieschi Morgan Stavroteki (Met Museum, Accession Number: 17.190.715a, b) (Resim 7), Kariye ve Tokalı Kilise örneklerinde Yusuf, Abdülmuttalip gibi sahnenin sağ tarafında yer alsa da Karanlık, Çarıklı ve Elmalı Kilise gibi örneklerde de sol tarafta yer almaktadır. İkisinin konumları bazı örneklerde farklı olsa da figürlerin duruşu ve fiziksel özelliklerinin fazlaca benzemesinden dolayı bu büyük bir zıtlık oluşturmamaktadır. Hz. Muhammed'in doğumu sahnesinde bir tabure üzerinde oturan Abdülmuttalib, bastonuna yaslanmış şekilde hafifçe kambur bir biçimde tasvir edilmiştir. İsa'nın doğumunda ise Yusuf bir kaya üzerine oturmuş ve kafasını ellerine dayayarak yine hafif kambur şekilde yer almaktadır.

25 İlgili görsel için bk. Coşkuner, Buket, “İsa’nın Doğumu'nun Yazılı ve Görsel Kaynakları: Kapadokya Örnekleri” Arkeoloji ve Sanat 133 (2010), 102.

${ }^{26}$ Sarnıç ve Çarıklı Kilisesindeki görseller için bk. Buket Coşkuner, 11. Yüzyılda Kapadokya Bölgesinde İsa'nın Doğumu ve İsa'nın Çarmıha Gerilme Sahneleri (Ankara Hacettepe Üniversitesi, Sosyal Bilimler Enstitüsü, Doktora Tezi, 2009), 204, 235.

${ }^{27}$ İlgili görsel için bk. Ayşegül Canverdi, Kapadokya Bölgesi Gözelöz (Mavrucan) ve Ortaköy Mevkiindeki Kiliselerin Duvar Resimlerindeki Sahnelerin İkonografisi (Kayseri: Erciyes Üniversitesi, Sosyal Bilimler Enstitüsü, Yüksek Lisans Tezi, 2005), 251. 
Abd-i Menaf kadınları olarak tanımladığımız uzun boylu figürler, İsa'nın doğumu sahnesindeki meleklerle ilişkilendirilebilir. Meleklerin Abd-i Menaf kadınlarıla ilişkilendirilebileceği en iyi örnekler çocuk İsa'nın yattığı yemliğin arkasında yan yana duran üç meleğin olduğu Sarnıç, Saklı Kilise ve Niğde Andaval Eski Gümüş Manastırı ve Yeni Tokalı Kilisesinde yer almaktadır. Daphne Manastırı ${ }^{28}$, Santa Maria in Trastevere Kilisesi ${ }^{29}$ ve Palatine Şapelindeki ${ }^{30}$ mozaiklerde, Sarnıç ve Saklı Kiliselerindeki duvar resimlerinde ve The Walters Art Museum'da bulunan fildişi levhada (The Walters Museum 71.375) iki veya daha fazla gruptan oluşan melek figürleri Meryem'in solunda yer almaktadır. Bunun dışında Louvre Müzesindeki bir triptikon (Louvre Museum, Département des Objets d'art du Moyen Age, OA 5004) (Resim 8), Kariye Kilisesi ve Yeni Tokalı Kilisesi'ndeki kompozisyonda melekler ve havari gruplarının birlikte yer aldığı görülebilmektedir. Theodore Psalter (British Library - Add MS 19352 -f.2r) resimli el yazmasındaki örnekte ise yemliğin sağ ve soluna yerleştirilen iki melek çocuk İsa'ya doğru yönelmişlerdir (Resim 9). Kariye Kilisesi'ndeki örnekte havarilerin arkasında bir meleğin kanadı ve gövdesi kısmen seçilebilmektedir. Melekler ve havariler, Abd-i Menaf kızları gibi doğum sonrası ziyareti temsil ettiğinden dolayı ikonografik açıdan benzer özellikler taşımaktadırlar.

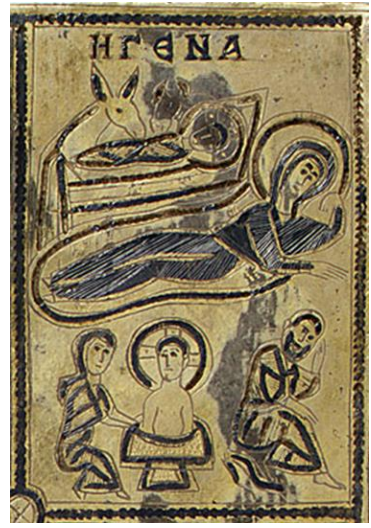

Resim 7. İsa'nın doğumu, (Met Museum, 17.190.715a,b).

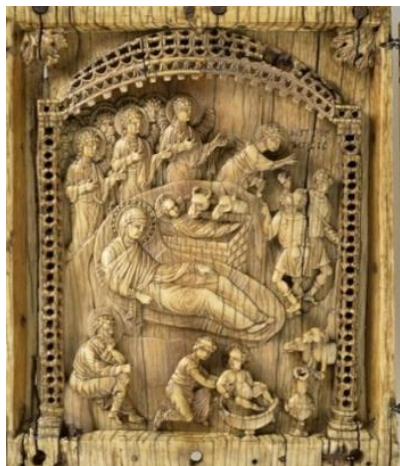

Resim 8. İsa'nın Doğumu, Louvre Museum (Louvre Museum, OA 5004).

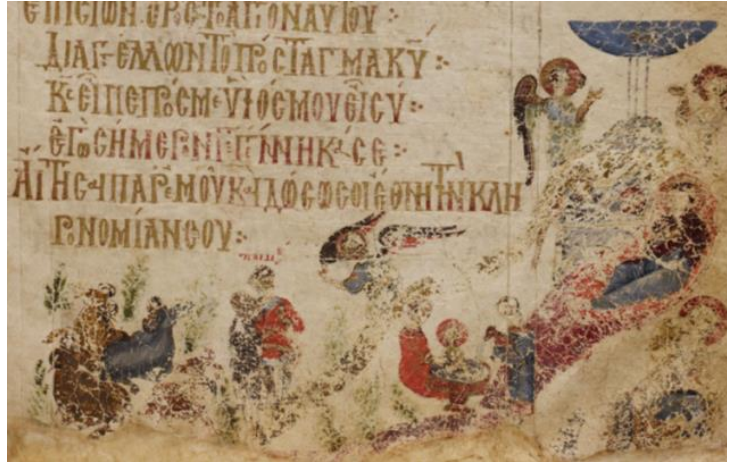

Resim 9. İsa'nın Doğumu (British LibraryAdd MS $19352-f .2 r)$.

\footnotetext{
${ }^{28}$ İlgili görsel için bk. Brubaker, Leslie. "The Virgin at Daphni",The Reception of the Virgin in Byzantium, Marian Narratives in Text and Images (New York,Cambridge Univercity Press, 2019), 129.

${ }^{29}$ İlgili görsel için bk. Hetherigton, Paul. "The Mosaics of Pietro Cavallini in Santa Maria in Trastevere", Journal of the Warburg and Courtauld Institutes 33 (1970), 23.

${ }^{30}$ Yapı içerisindeki mozaikler hakkında daha ayrıntılı bilgi için bk. Kitzinger, Ernst, "The Mosaics of the Capella Palatine in Palermo: An Essay on the Choice and Arrangement of Subjects", The Art Bulletin 31/4 (1949), 269-292.
} 
Doğum sahneleri bütüncül olarak değerlendirildiğinde Hz. Muhammed'in doğum sahnesinin İslamî dönem yazılı kaynaklarına dayandığı, ancak tasvire dönüşüm sürecinde Hristiyan sanatında daha önce tasvir edilmiş olan Meryem ve İsa'nın doğumu sahnelerindeki mekân, figür özellikleri ve figürlerin dağılımı gibi çeşitli açılardan etkilendiği anlaşılmaktadır. ${ }^{31}$

İkinci örneğimiz " $H z$. Muhammed'e Peygamberliğin tebliğ edildiği" sahnedir. Buradaki kompozisyon Bizans sanatı içerisinde çeşitli örnekleri bulunan Meryem'e Müjde sahnesi ile benzerlik göstermektedir.

Meryem'e İsa'nın Müjdelenmesi Kanonik İncillerden sadece Luka'da anlatılmakla birlikte, Apokrif İncillerde çok daha fazla bilgiye rastlanmaktadır. Luka'da aktarılana göre Tanrı, Meryem'e Cebrail'i göndermiş ve ona adını İsa koyacağı bir çocuk doğuracağı mesajını ileterek İsa'yı müjdelemiştir (Luka 1: 26-29). Apokrif Yakup İncili'nde ise kuyudan su doldurmak için testiyle dışarı çıkan Meryem'e bir ses İsa'yı müjdeler ve bundan korkan Meryem evine giderek ip eğirir (Apokrif Yakup İncili 11: 1-2).

Bizans ve İslamî dönem sahneleri arasında kıyaslama yapmadan önce incelediğimiz Câmiu'tTevârîh yazması (Or. Ms. 20) içerisindeki Meryem'e müjde (f.22r) ve Hz. Muhammed'e tebliğ sahnelerine değinmekte fayda vardır. Her iki sahnede de dağlık bir arka plan önünde iki figür görülmektedir. İki sahnede de kutsal kişiler sağda, melek figürleri ise solda yer almaktadır. Hz. Muhammed'e tebliğ sahnesinin kompozisyonları Bizans resim sanatı kaynaklı olmakla birlikte bu yazma içerisindeki Meryem'e Müjde sahnesinin arka planı İslamî kaynaklıdır. Hristiyan sanatında görülen Meryem'e müjde sahnelerinde mekân olarak bir konutu temsil eden mimari öğe ya da bahçe içerisindeki kuyu başı tercih edilmiştir. Ancak burada Apokrif kaynaklı bilgilerin tasvir edilişinde farklı bir mekân seçilmiş ve Meryem dağlık bir alanda, bir su kuyusu başında elinde su testisi ve üzerinde mavi/erguvan bir örtü ile ayakta tasvir edilmiştir. ${ }^{32}$ Ayrıca karşısındaki melek, İslamî anlatıma uygun olarak insan şeklinde gösterilmiştir. ${ }^{33}$ Câmiu't-Tevarih içerisindeki Meryem'e müjde (f.22r) sahnesinin benzer örnekleri Meryem'in elinde su testisi taşıması bakımından San Marko Kilisesindeki mozaik ve British Museum'daki bir madalyonda (1973,0501.1) görülmektedir. Ayrıca San Marko Kilisesindeki örnekte Meryem kuyu başında tasvir edilmiştir.

İncelediğimiz Hz. Muhammed'e Peygamberliğin tebliğ edildiği sahne ile Bizans sanatındaki Meryem'e müjde sahneleri arasındaki temel farklılık kompozisyonların arka planları yani olayın gerçekleştiği mekânda ortaya çıkmaktadır. Hz. Muhammed dağlık bir alandayken, Meryem ya bir mekân önünde otururken ya da bahçede kuyunun yanında tasvir edilir. Mekân anlamında ne kadar

31 1594-95 yıllarına tarihlenen Siyer-i Nebi yazmasında Hz. Muhammed'in doğumu bir iç mekânda geçer ve Câmiu't-Tevârîh'teki pek çok ayrıntıdan da arınmış bir haldedir. Daha çok sembolik bir anlatım dili içerisinde ele alınan sahnede dua eder vaziyette Hz. Âmine ve ellerinde ibrik, kâse, peştamal tutan üç meleğin önünde henüz yeni doğmuş ve kundaklanmış şekilde Hz. Muhammed tasvir edilmiştir (TMSK, Hazine 1221, 223b). Bu minyatürde sahnenin İslamî dönem kaynaklarında geçen anlatıma göre biçimlendirildiği görülmektedir.

${ }^{32}$ Hazine 1654 no'lu Farsça Câmiu't-Tevârîh yazmasında ise aynı sahnede (f.31v) Meryem ile Cebrail'in arasında bir dere akmaktadır (İnal, 1963, 168-169). İnal, bu sahneyi Edinburgh nüshasındaki sahnenin (Or. Ms. 20, f.22r) c1lız bir taklidi olarak nitelemektedir (İnal, 1976, 76). Benzer bir kompozisyon Timurlu dönemine tarihlenen yaklaşık 1425 tarihli Mecmâ el-Tevârîh nüshasında da Herat üslubu içerisinde ele alınarak tekrarlanmıştır (Metropolitan Museum, Accession Number: 57.51.37.3).

33 El-Âsâr'il-Bâkiye an'il-Kurûni'l-Hâliye isimli yazmanın 16. yüzyıla tarihlenen bir nüshasında Meryem sahnenin solunda kemerli bir mekân içerisinde ip bükerken verilmiştir. Bağdaş kurmuş vaziyette oturan Meryem Orta Asya figür tipine uygun olarak resmedilmiş, ancak kıyafetleri Hristiyan tipindedir (İnal, 1976, 64). Meryem'in karşısındaki melek figürü ise Câmiu't-Tevârîh’teki örnekten farklı olarak kanatlı ve haleli olarak işlenmiştir (Paris Bibliothétque Nationale, Arabe 1489, 162v). 
farklılık söz konusu ise figürlerin konumlanışları ve duruşları arasında da bir o kadar benzerlik görülmektedir. Çavuşin, Tağar ${ }^{34}$, Mavrucan Haç̧, Tokalı (Resim 10), Tavşanlı ve Pancarlık Kiliselerindeki duvar resimlerinde ${ }^{36}$, Dumbarton Oaks koleksiyonunda yer alan iki sikkenin (BZS. 1958.106.1846 - BZS.1958.106.1334) arka yüzlerinde, St. Catherine Manastırındaki ${ }^{37}$ bir ikonada (Resim 11) ve Bristol Psalter (Resim 12) ve Dumbarton Oaks'taki bir minyatürde (Dumbarton Oaks, BZ.1962.35, f.80v) Meryem ve melek figürlerinin karşılıklı olarak konumlandığı ve olayın geçtiği yerin belli olması amacıyla Meryem'in arkasına veya yakınına mimari öğeler yerleştirildiği görülmektedir.

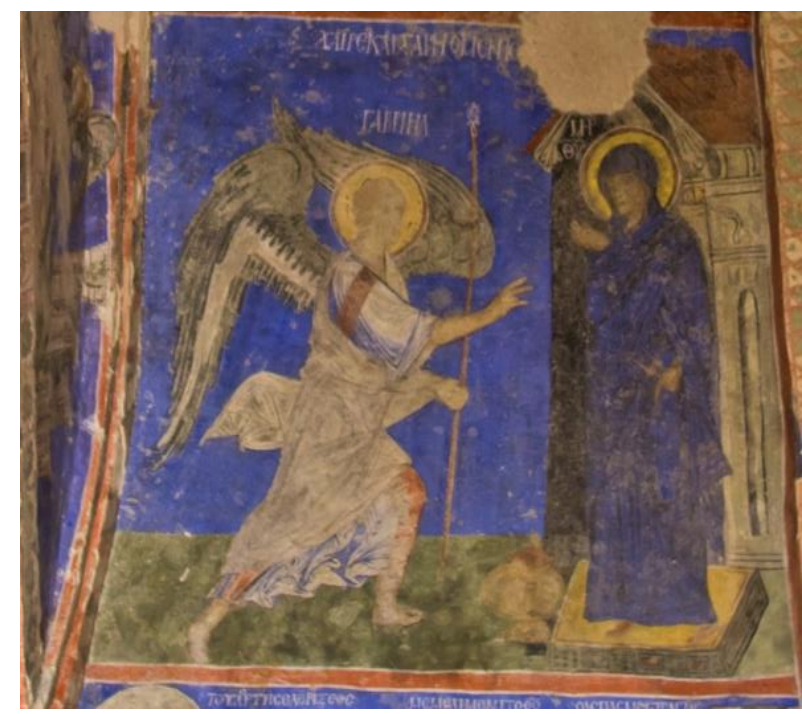

Resim 10. Meryem'e Müjde - Tokalı Kilise (Antoine Taveneaux).

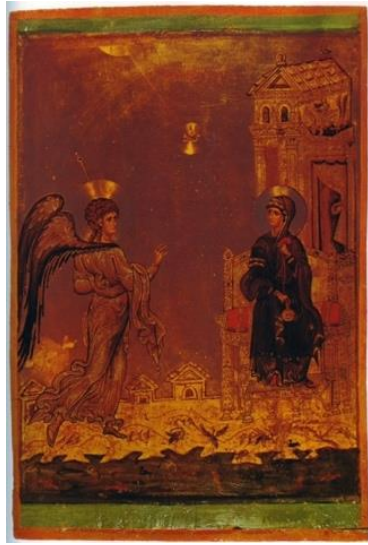

Resim 11. Meryem'e Müjde (St. Catherine Manastırl).

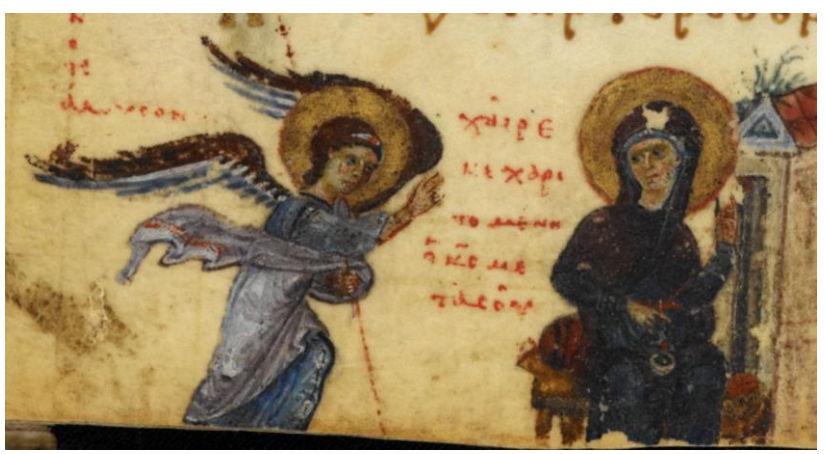

Resim 12. Meryem'e Müjde (British Library - Add MS $40731-f .74 v)$.

\footnotetext{
${ }^{34}$ İlgili görsel için bk. Fazilet Koçyiğit, "Tağar (St. Theodore) Kilisesi Duvar Resimleri”, Erciyes Üniversitesi Sosyal Bilimler Enstitüsü Dergisi 1/26 (2019), 161.

${ }^{35}$ İlgili görsel için bk. Ayşegül Canverdi, Kapadokya Bölgesi Güzelöz (Mavrucan) ve Ortaköy Mevkiindeki Kiliselerin Duvar Resimlerindeki Sahnelerin İkonografisi, 250.

${ }^{36}$ İlgili görseller için bk. Robert G. Ousterhout, Visualizing Community, Art, Material Culture and Settlement in Byzantine Cappadocia (Washington: Sheridan Books, 2017), 181-187.

${ }^{37}$ Sina Dağı keşişlerinin, bedevi kabileleri tarafindan rahatsız edilmesi üzerine I. Justinianus tarafından 545 yılında yaptırılan, günümüzde Mısır sınırları içerisinde bulunan manastır (Atiya, 1952, 578).
} 
İncelenen minyatürde Hz. Muhammed oturur şekilde gösterilmiş, ona karşıllk gelen Meryem figürü ise Dumbarton Oaks'taki minyatür (Dumbarton Oaks, BZ.1962.35, f.80v), Mavrucan, Haç, Tokalı ve Pancarlık Kiliselerindeki duvar resimleri ve British Museum'daki madalyon (1973,0501.1) örnekleri dışındaki tüm örneklerde otururken tasvir edilmiştir. Melek tasvirleri tüm örneklerde Cebrail'in Hz. Muhammed'i işaret ettiği gibi Meryem'i işaret eder şekilde verilmiştir.

Genel olarak değerlendirildiğinde müjde ve tebliğ sahnelerinde mekânsal benzerlikten ziyade figürlerin konum ve birbiriyle ilişkileri bağlamında bir benzerlik bulunduğu görülmektedir.

Üçüncü ve son örneğimiz olan "Beni Nadir Kabilesi kuşatması" sahnesi Bizans ve Hristiyan sanatında sıkça gördüğümüz İsa'nın Kudüs'e girişi sahnesiyle benzerlikler içermektedir.

İsa'nın Kudüs'e girişi İncil'in Matta 21: 1-11, Luka 19: 28-40, Yuhanna 12: 12-19 ve Markos 11: 1-11 ayetlerinde bahsedilmektedir. Kanonik İnciller arasında bu olay üzerinde birbirinden farkl1 anlatımlar görülmez. Ancak Matta İncili daha ayrıntılı bilgiler verdiğinden incelemede Matta İncili esas alınmıştır.

Matta İncili'nde anlatılana göre İsa ve Havarileri Kudüs'e yaklaşırken Beyfacı Köyüne varırlar ve İsa iki öğrencisinden köyde bağlı olan dişi bir eşek ve sıpayı kendisine getirmesini ister. Sonrasında İsa sıpanın üzerine binip Kudüs'e doğru hareket eder. İsa'yı gören halk ise onu ağaçlardan koparttığı dalları ve üzerlerinden çıkardıkları kıyafetlerini yola sererek coşkuyla karşılar (Matta 21: 1-11).

Her iki kompozisyonun da merkezinde peygamber figürleri yer almaktadır. İsa'nın İncil'de aktarıldığı üzere sıpa üzerinde Kudüs'e yöneldiği, Hz. Muhammed'in ise at üzerinde Beni Nadir Kabilesinin muhkem yapılarından birisine yaklaştığ görülmektedir. İsa'nın bindiği sıpa tüm örneklerde hareket halindeyken, Hz. Muhammed'in atı durağan vaziyettedir.

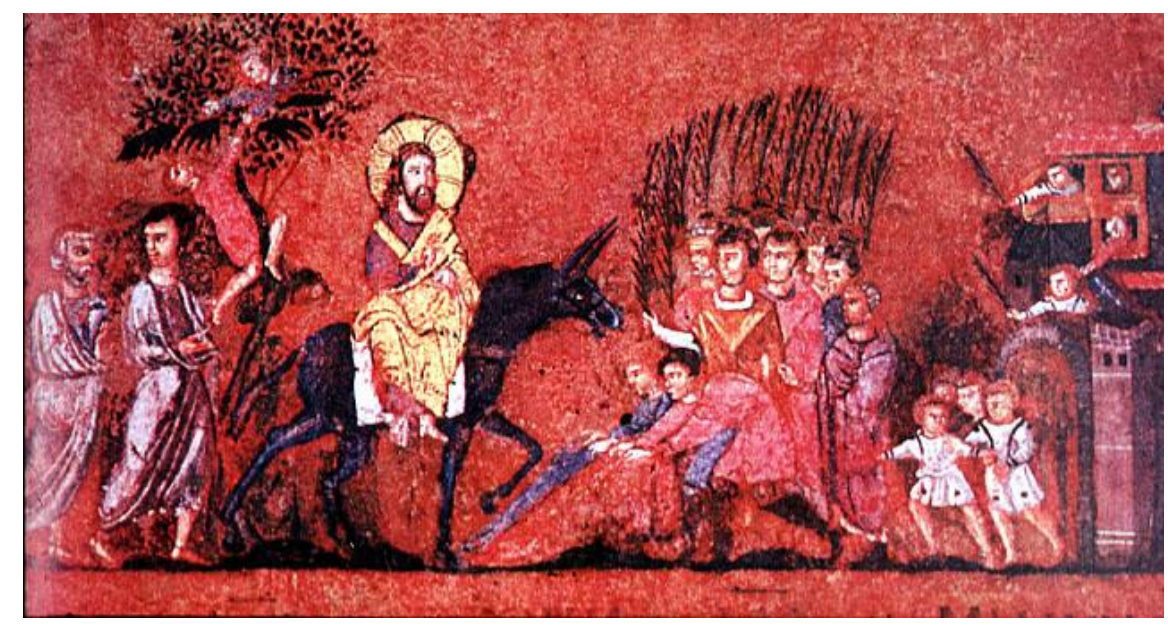

Resim 13. İsa'nın Kudüs'e Girişi (Gregory-Aland no.042, f.1v).

Ele alınan minyatüre en fazla benzeyen kompozisyonlar, Rossano İncili’ndeki, ${ }^{38}$ minyatürde (Gregory-Aland no.042, f.1v) (Resim 13), Berlin Müzesindeki fildişi bir levhada (Staatliche Museen zu Berlin, Ident Nr. 1590), Palatine Şapeli (Resim 14) ve San Marko Kilisesi'ndeki ${ }^{39}$ mozaiklerde görülmektedir. Bu örneklerde İsa'nın yüzü, Hz. Muhammed'in yüzü gibi 3/4 oranında şehre doğru

\footnotetext{
${ }^{38}$ Rossano İncilinin, Viyana Genesis yazması ile olan benzerliğinden dolayı 6. yüzyılın ikinci yarısına ait olduğuna dair bir fikir birliği mevcuttur. Ancak kesin olarak nerede, ne zaman ve kim tarafından yapıldığı bilinmemektedir (Serdar Dinçer, 2019, 408).

39 İtalya'nın Venedik şehrinde bulunan San Marco Bazilikası 829 yılında İskenderiye'den getirilen Aziz Markos'un kalıntılarını muhafaza etmek için Doge Sarayının yanına inşa edilmiş ve saray şapeli olarak hizmet vermiştir (Britannica, "San Marco Basilica”, Erişim 1 Şubat 2020).
} 
bakar vaziyette tasvir edilirken; Vatopedi ${ }^{40}$ ve St. Catherine manastırı ikonalarında, St. Stephan Kilisesindeki ${ }^{41}$ ve Hosios Loukas Manastırının kripta katındaki duvar resimlerinde (Resim 15) ise İsa'nın yüzü izleyiciye bakar vaziyettedir. Buradaki en büyük fark peygamber figürlerinin duruş pozisyonlarındadir ${ }^{42}$.

İsa'nın sıpa üzerindeki duruş pozisyonları Batı ve Doğu sanatında farklılıklar gösterir. Batıda görülen kompozisyonların erken örnekleri Helenistik kökenli olması sebebiyle İsa sıpa üzerinde ata biner gibi tam bir oturuş sergilemektedir. Buna karşılık özellikle Suriye ve Mısır bölgesinde ortaya çıkan örneklerde ise yan bir oturuş görülmektedir. Doğuda görülen bu oturuş şekli Bizans eserlerinde de tekrarlanmıştır (Smith, 1918, 121-128). Ancak ele alınan Beni Nadir Kabilesi kuşatması minyatüründe Hz. Muhammed at üzerinde ideal bir oturuş düzeninde verilmiştir.

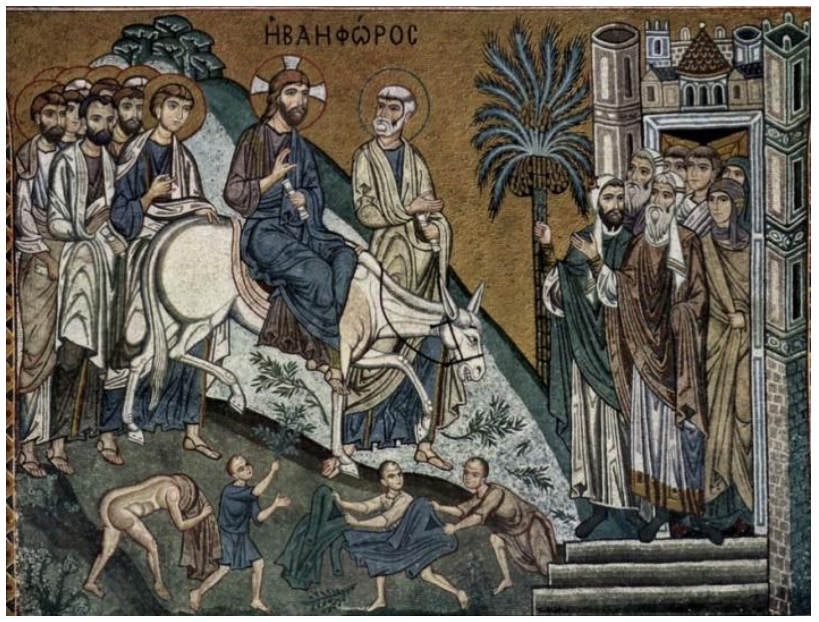

Resim 15. İsa'nın Kudüs'e Gelişi - Palatine Şapeli.

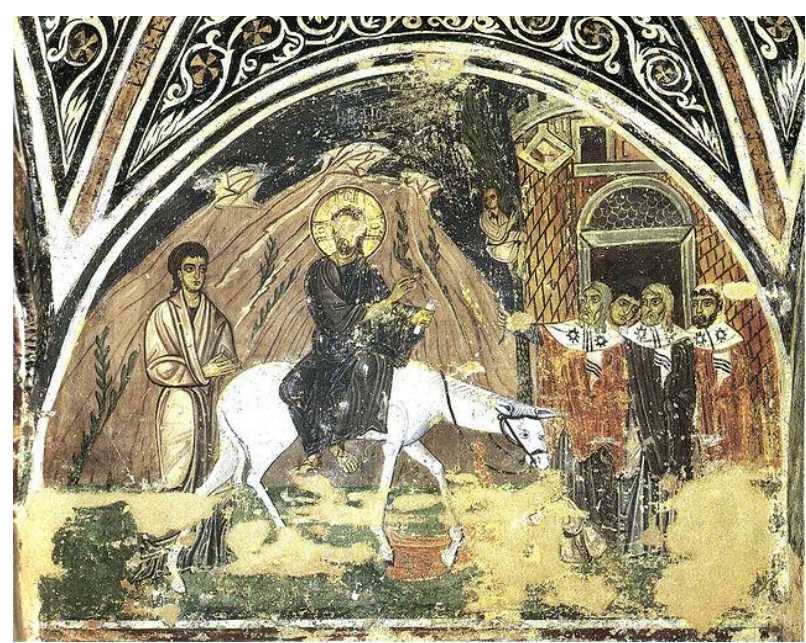

Resim 16. İsa'nın Kudüs'e Girişi - Hosios Loukas Manastırı

\footnotetext{
${ }^{40}$ Yunanistan'ın Athos Dağı eteklerinde bulunan bu manastııın yapımına ilişkin iki rivayet vardır. Bunlardan birincisi I. Theodosius (M.S. 347-395) döneminde inşa edildiğidir. İkincisi ise Athanasios, Nicholas ve Antony isimli üç arkhon'un Edirne'den Athos'a gelerek harap bir manastırı restore ederek Vatopedi Manastırının kurulmasıdır. Bu konu üzerindeki ilk belgesel kanıt 985 yılına ait bir yazmada manastır yöneticisi olan Nicholas'ın imzasının bulunmasıdır (Kazdhan, 1991, 2155).

${ }^{41}$ Yunanistan'ın, Kalambaka şehrinde yer alan kilise 14. yüzyılda Aziz Stephan adına inşa ettirilmiştir (Daniilia vd., 2008, 2474).

${ }^{42}$ Vatopedi Manastırı, St. Nicholas ve San Marco Kilisesindeki örnekler için bk. https://pravoslavie.ru/
} 
Peygamberlere eşlik eden figürlere bakıldığında Hz. Muhammed'in arkasında ikili ve onların arkasında dörtlü olmak üzere toplamda iki grup halinde altı asker görülmektedir. Vatopedi Manastırındaki ikonada ve Rossano İncilindeki (Gregory-Aland no.042, f.1v) minyatürde İsa'nın arkasında sadece iki havari, diğer tüm örneklerde ise arka arkaya dizilmiş kalabalık havari grupları tasvir edilmiştir. Bu anlamda en farklı örneği İsa'nın ardından gelen hiçbir figürün olmamasıyla Bristol Psalter ${ }^{43}$ (British Library - Add MS 40731, f.15v) yazmasındaki minyatür göstermektedir. Örneklerden görüldüğü üzere Kudüs'e giriş sahnelerindeki figürlerde tek tip kompozisyon karşımıza çıkmaz. Hz. Muhammed'in hemen arkasındaki asker grubunun iki figürden oluşması bakımından Vatopedi Manastırındaki ve Rossano İncili’ndeki örnekler Beni Nadir kabilesi minyatürüyle daha fazla benzerlik göstermektedir.

Tasvirlerde Hz. Muhammed'in ve İsa Peygamberin yöneldiği bir şehir yapısı mevcuttur. Bu şehir yapıları Beni Nadir minyatüründe kale olarak, Kudüs'e giriş sahnelerindeyse surlarla çevrili bir bölge/Kudüs şehri olarak tasvir edilmiştir. San Marko Kilisesi'ndeki mozaik dışındaki örneklerin hepsinde surlar içerisinde yapılar da işlenmiştir. Bu bağlamda en ayrıntılı şehir tasviri St. Nicholas Kilisesi'nde ${ }^{44}$ yer alan duvar resminde görülmektedir.

Şehir önünde gelenleri karşılayan figürler Beni Nadir Kabilesinde şehir kapısının önünde ve yapı içerisinde olmak üzere iki figür grubundan oluşmaktadır. Bu hususta Kudüs'e girişs sahnelerinde kalıplaşmış, tek tip bir kompozisyon görülmez. Örnek olarak Rossano İncili ve Bristol Psalter'daki minyatürlerde hem şehir önünde hem de şehir içinde figür grupları gelenleri karşılarken; diğer örneklerde sadece şehir önünde figürler görülmektedir.

9. yüzyılda üretilen Paris Gregory ${ }^{45}$ yazmasıyla (Bnf Gr.510 -f.196v) birlikte İsa'nın Kudüs'e girişi sahnelerinde bir gelişim görülmektedir. Bu yazmadaki örnekte İsa'yı takip eden havarilerin sayısının on iki olması ve şehir önünde bekleyen figürlerin artmasıyla daha güçlü bir etki meydana getirilmiştir. Böylelikle Codex Egberti (997-993) ${ }^{46}$ yazmasındaki minyatür ve Sant'Angelo in Formis Bazilikası'ndaki ${ }^{47}$ duvar resmi gibi örneklere bakıldığında İsa'nın sıpa üzerinde oturuşunda Helenistik dönem etkileri görülürken, figürlerin yoğun olarak kullanılması Bizans kaynaklı bir yaklaşımdır. Batı kaynaklı örneklere baktığımızda Bizans etkisinin 9. yüzyıldan sonra buraya da yayıldığı ve ikonografik kompozisyonları değiştirdiği görülmektedir (Smith, 1918, 121-128).

Beni Nadir kuşatması minyatürü ve Kudüs'e giriş sahneleri arasında biçimsel bir etkileşimin olmasının yanında bazı farklar da görülmektedir. İki kompozisyon arasındaki temel fark sahnenin merkezindeki Hz. Muhammed ve İsa Peygamberin binek hayvanları ve duruş pozisyonlarıdır. İncil'de belirtildiği üzere İsa'nın sıpa üzerinde olması yazılı bir kaynağa dayanmaktadır. Ayrıca İsa sıpa üzerinde yan vaziyette otururken, Hz. Muhammed ise at üzerinde ideal bir oturuşta resmedilmiştir. Ancak Hz. Muhammed'in at üzerinde olduğuna dair herhangi bir yazılı kaynak yoktur. Bildiğimiz tek husus askerleriyle Beni Nadir kabilesini on beş gün kuşatma altında tuttuğudur. Diğer figürlere

${ }^{43}$ British Library'de Add MS 40731 raf numaralı, resimli Bizans el yazmasıdır. 11. yüzyılda İstanbul'da üretildiği düşünülen Psalter, Mezmurlar olarak da bilinen bir dua kitabıdır (British Library, "Bristol Psalter", (Erişim 1 Şubat 2020)).

${ }^{44}$ Yunanistan'ın, Kalambaka şehrinde yer alan kilise 14. yüzyılda Aziz Stephan adına inşa ettirilmiştir (Daniilia vd., 2008, 2474).

${ }^{45}$ 879-883 yılları arasına tarihlenen, İstanbul'da üretilmiş olan Paris Gregory yazması, İkonoklast dönemden sonra üretilmiş en yoğun minyatür içeren Bizans yazmalarından birisidir. Günümüzde Paris Ulusal Kütüphanesi'nde Gr.510 raf numarası ile muhafaza edilmektedir (Brubaker, 1985, 1).

${ }^{46}$ Wissenschaftliche Bibliothek der Stadt Trier, "Der-Egbert-Codex", (Erişim 23 Mart 2020).

${ }^{47}$ Sant'Angelı in Formis Bazilikası, 11. yüzyılda başrahip Abbot Desidero tarafindan MÖ 5. yüzyıla tarihlenen Roma tapınağı üzerine kurulmuştur. Güney İtalya'da bulunan bu kilise, Eski ve Yeni Ahitten alınan sahnelerin yapıldığı duvar resimleriyle bilinir (Cammarota vd., 2013, 225). 
bakıldığında İsa'yı havarileri takip ederken ve Kudüs'te halk karşılarken, Hz. Muhammed'i karşllayanlar da takip edenler de askerlerdir.

Beni Nadir Kabilesi kuşatması minyatürü ve Kudüs'e giriş sahneleri arasında mekân ve figür dağılımı gibi pek çok konuda yakın benzerlikler söz konusudur. Özellikle San Marco Kilisesi mozaiğ $i^{48}$ ve Rossano İncilindeki minyatürde figürlerin konumları ve birbirlerine olan mesafeleri dikkate alındığında bu benzerlik çok daha somut bir halde görülebilmektedir.

İslam sanatında hiçbir öncü örneği bulunmayan bu tasviri yapan nakkaşın etkileneceği ve örnek alabileceği kompozisyon Hristiyan sanatında bulunmuş olmalıdır. Câmi'ut-Tevârîh'i yazan kurul arasında Hristiyan rahiplerinin de olduğu göz önüne alındığında Beni Nadir Kabilesi kuşatması minyatürünün, İsa'nın Kudüs'e giriş sahnesinden biçimsel anlamda esinlenerek yapıldığı, Hz. Muhammed'in olduğu diğer tasvirlerdeki gibi açıkça ortadadır.

Bütün bu veriler 1şığında Câmi'ut-Tevârîh'in erken tarihli iki nüshasında figürlerin biçimlendirilmesinde Selçuklu resim okulunun etkisinin ağır bastığı, buna karşın manzaralarda ise Uzak Doğu etkisinin ön planda olduğu görülmektedir (İnal, 1976, 72). Buna göre sanatçıların önyargılardan uzak bir şekilde farklı kaynak ve kökenlerden beslenmesi zengin bir tasvir anlayışının oluşumuna imkân sağladığı anlaşılmaktadır.

\section{SONUÇ}

Câmiu't-Tevârîh'in tarihçesine ve yazım sürecine bakıldığında pek çok milletten yetkin insanların katkıları açıkça görülmektedir. Câmiu't-Tevârîh'in tek bir kişinin elinden çıkmaması eserin içerik açısından objektifliğini ön plana çıkarmasının yanı sıra minyatürlerdeki kompozisyon düzenlerinde de yoğun bir üslup etkileşimine imkân tanımıştır.

Câmiu't-Tevârîh yazmalarındaki minyatürlerin büyük bir çoğunluğu farklı kökenlerden beslense de Peygamber tasvirlerinin büyük bir çoğunluğun Bizans kaynaklı olduğu açıktır (Allen, 1985, 121). Çalışmada ele alınan "Hz. Muhammed'in Doğumu”, "Hz. Muhammed'e Peygamberliğin Tebliğ Edilmesi” ve "Beni Nadir Kabilesi Kuşatması" minyatürlerinde de söz konusu etkileşim açıkça görülmektedir. Bu minyatürler konu bakımından İslamî kaynaklı olsa da kompozisyon düzenlemesi, figürlerin işlenişi gibi pek çok bakımdan Hrıstiyan/Bizans sanatında yer alan "Meryem'in ve İsa'nın Doğumu", "Meryem'e Müjde" ve "İsa'nın Kudüs'e Girişiı" sahneleriyle oranlanı değişmekle birlikte yoğun bir etkileşim içerisindedirler. İncelenen üç minyatürde de ele alınan kompozisyonun metinle desteklenmediği görülmektedir. Nitekim resim-metin ilişkisinin kurulamadığı bu sahnelerde sanatçının farklı kaynaklardan beslenmesi makul bir yaklaşımdır. Yukarıda da ifade edildiği üzere Câmiu'tTevârîh'in hazırlanış sürecinde geniş katılımlı bir heyetin olduğunu ve bu heyetin içerisinde Hristiyan bir rahibin bulunduğu da bilinmektedir. $\mathrm{Bu}$ bağlamda söz konusu sahnelerin bilinen kompozisyonlardan yola çıkılarak, yeniden kurgulandığı söylenebilir.

İslam Dininin madde dünyasındaki şekiller ve tasavvurlardan uzak ilah kavramı ve Hristiyanlıktaki gibi aziz/kutsal kişi anlayışının olmaması İslam sanatında ikonografik tasvirlerin nispeten az olmasının ana sebebidir. İslam dinine mensup sanatçılar, bu yüzden gördüklerini olduğu gibi tasvir etmek yerine, onları yorumlayarak üsluplaştırmayı/stilize etmeyi tercih etmişlerdir (Çam, 2012, 90-91). Kur'an-1 Kerim'de tasvire karşı kesin bir yasak olmamasına rağmen sanatçılar, Allah ve peygamber tasvirleri yapmaktan kaçınmışlardır. Bu uygulama sadece tasvir edilene tapınma gibi bir eylemden kaçınmak için değil aynı zamanda tasvir edilen kutsal figürün insan elinden kusurlu olarak meydana geleceği düşüncesiyle de gerçekleşen bilinçli bir tercihtir (Koç, 2018, 193-194).

\footnotetext{
${ }^{48}$ İlgili görsel için bk. Scala Archives, "Entry of Jesus into Jerusalem”, (Erişim 15 Haziran 2021).
} 
Tasvirin hoş görülmediği bir ortamda Hz. Muhammed konulu minyatürler üretmek, ikonografik gelenekten gelmeyen Müslüman sanatçılar için oldukça zor olmuş ve kompozisyonların nasıl düzenleneceği sorusu ortaya çıkmış olmalıdır. Bu nedenle temas halindeki yakın din ve kültürlerle bir etkileşim de kaçınılmaz hale gelmiştir. Nitekim incelediğimiz minyatürler konularını her ne kadar İslam tarihinden alsalar da, Bizans resim geleneği etkisinde tasvir edildikleri açıkça görülmektedir. Eseri yazan kurul içerisinde Hristiyan rahiplerin olması da bu durumu desteklemektedir.

İncelediğimiz minyatürlerde Hz. Muhammed'in tasvir edilmesi İslam sanatı açısından bir tezatlık doğurmaktan ziyade metinde aktarılan bilginin pekiştirilmesini hedefleyen tarihsel bir amaç gütmektedir. Ortodokslardaki ikona geleneğinde olduğu gibi tapınma amaçlı olmayan bu minyatürlerde Hz. Muhammed'in tasvir edilmesi eserin yapılış amacı bakımından da bir uygunsuzluk taşımamaktadır. ${ }^{49}$

Sonuç olarak Câmiu't-Tevârîh yazmaları görece geniş katılımlı bir komisyon tarafından hazırlanmış metinleri, farklı din ve kültürlerden beslenen tasvir anlayışları ile İslam tarih ve sanat anlayışının kurumsallaşmasına giden yolda önemli basamaklardan birisidir.

Author Contributions / Yazarların Katkısı: This article is a work with two-authors. The contribution of the aforementioned authors to the preparation of the article is equal. / Bu makale, iki yazarlı bir eserdir. Makalenin hazırlanmasına söz konusu yazarların katkısı eşittir.

Funding / Finansman: This research received no external funding. / $\mathrm{Bu}$ araştırma herhangi bir diş fon almamıştır.

Conflicts of Interest / Çıkar Çatışması: The author declare no conflict of interest. / Yazar, herhangi bir çıkar çatışması olmadığını beyan eder.

\section{KAYNAKÇA}

Adıgüzel, Osman. Hz. Peygamber'in Dedesi Abdülmuttalib ve Halalarının Hayatları. Şanlıurfa: Harran Üniversitesi, İslam Tarihi ve Sanatları Ana Bilim Dalı, Yüksek Lisans Tezi, 2018.

Aga-Oglu, Mehmet. "Preliminary Notes on Some Persian Illustrated MSS. in the Topkapu Sarayi Müzesi: Part I". Ars Islamica 1/2 (1934), 183-199.

Allen, Terry. "Byzantine Sources for the Jāmi' al-tāwarīkh of Ra shīd Al-Dīn" Ars Orientalis 15 (1985), 121-136.

Arletti, Rossella vd. "A study of glass tesserae from mosaics in the monasteries of Daphni and Hosios Loukas (Greece)". Archaeometry 52/5 (2010), 796-815.

Atiya, Aziz S. "The Monastery of St. Catherine and the Mount Sinai Expedition". Proceedings of the American Philosophical Society 96/5 (1952), 578-586. https://www.jstor.org/stable/3143659

Blair, Sheila. "Illustrating History: Rashid al-Din and his Compendium of Chronicles". Iranian Studies 50/6 (02 Kasım 2017), 819-842. https://doi.org/10.1080/00210862.2016.1268376

Bozkurt, Nebi - Küçükaşçı, Mustafa Sabri. "Medine”. TDV Íslam Ansiklopedisi. 305-311. Ankara: TDV Yayınları, 2003.

Brubaker, Leslie. "Politics, Patronage, and Art in Ninth-Century Byzantium: The 'Homilies' of Gregory of Nazianzus in Paris (B. N. gr. 510)”. Dumbarton Oaks Papers 39/ (1985), 1-13. https://doi.org/10.2307/1291513

Brubaker, Leslie. "The Virgin at Daphni”. The Reception of the Virgin in Byzantium: Marian Narratives in Texts and Images. ed. Mary B. Cunningham - Thomas Arentzen. 120-148. Cambridge: Cambridge University Press, 2019. https://doi.org/10.1017/9781108696791.006

Cammarota, A. vd. "The Benedictine Basilica of S. Angelo in Formis (Southern Italy): A therapy without diagnosis?" Geotechnical Engineering for the Preservation of Monuments and Historic Sites, 225.

\footnotetext{
${ }^{49}$ Varka ile Gülşah Mesnevisi, El-Âsâr'il-Bâkiye an'il-Kurûni'l-Hâliye, Câmi'ut Tevârîh, Miraçname (TMSK, Hazine 2154) gibi İslam tasvir sanatının erken dönem (13. yüzyılın ortaları-14. yüzyılın ortaları) örneklerinde görülen Hz. Muhammed tasvirleri 16. yüzyılda değişim geçirmiştir. Zübdetü’t-Tevârih (1583) ve Siyer-i Nebi (1594-95) gibi eserlerde Hz. Muhammed'in sadece siluet halinde verilmesi, yüzünün peçe ile kapatılması, bir hale/bir 1şık demeti içerisinde gösterilmesi ya da bütünüyle 1 şık topu şeklinde gösterilmesi yaygınlık kazanmıştır.
} 
Canverdi, Ayşegül. Kapadokya Bölgesi Gözelöz (Mavrucan) ve Ortaköy Mevkiindeki Kiliselerin Duvar Resimlerindeki Sahnelerin Ikonografisi. Kayseri: Erciyes Üniversitesi, Sosyal Bilimler Enstitüsü, Yüksek Lisans Tezi, 2005.

Coşkuner, Buket. 11. Yüzyılda Kapadokya Bölgesinde İsa'nın Doğumu ve İsa'nın Çarmıha Gerilme Sahneleri. Ankara: Hacettepe Üniversitesi, Sosyal Bilimler Enstitüsü, Doktora Tezi, 2009.

Coşkuner, Buket. "İsa'nın Doğumu'nun Yazılı ve Görsel Kaynakları: Kapadokya Örnekleri". Arkeoloji ve Sanat 133 (2010), 101-114.

Çam, Nusret. İslamda Sanat Sanatta İslam. Ankara, 2012.

Çelik, Remziye. Reşî̀üddin Fazlullah-ı Hemedânî ve Câmi'ut-Tevârîh. İstanbul: İstanbul Üniversitesi, Sosyal Bilimler Enstitüsü, Yüksek Lisans Tezi, 2016.

Daniilia, Sister vd. "From Byzantine to post-Byzantine art: the painting technique of St Stephen's wall paintings at Meteora, Greece". Journal of Archaeological Science 35/9 (2008), 2474-2485.

Dixon, Graham. "The Cappella of S. Maria in Trastevere (1605-45): An Archival Study". Music \& Letters 62/1 (1981), 3040.

Ebul Hasen Ali en-Nedvi. Son Peygamber Hz. Muhammed'in Hayatı. İstanbul, 1992.

Eyice, Semavi. "Kariye Camii”. TDV İslam Ansiklopedisi. 24/495-498. Ankara: TDV Yayınları, 2001.

Fayda, Mustafa. “Abdümenâf b. Kusay”. TDV İslam Ansiklopedisi. 287-288. Ankara: TDV Yayınları, 1988.

Ghiasian, Mohamad Reza. "The Topkapı Manuscript of the Jāmi ' al-Tawārikh (Hazine 1654) from Rashidiya to the Ottoman Court: A Preliminary Analysis". Iranian Studies 51/3 (2018), 399-425. https://doi.org/10.1080/00210862.2018.1428085

Gray, Basil. "An Unknown Fragment of the "Jāmi' al-tawārīkh" in the Asiatic Society of Bengal". Ars Orientalis 1 (1954), 65-75.

Gray, Basil. La Peinture Persane. Cenevre: Skira Flammarion, 1977.

Günel, Fuat. "Hira”. TDV İslam Ansiklopedisi. 121-122. Ankara: TDV Yayınları, 1998.

Hamidullah, Muhammad. İslâm Peygamberi, Ankara, 2003.

Harman, Ömer Faruk. "Buhtunnass”. TDV İslam Ansiklopedisi. 380-381. Ankara: TDV Yayınları, 1992.

Hetherington, Paul. "The Mosaics of Pietro Cavallini in Santa Maria in Trastevere". Journal of the Warburg and Courtauld Institutes 33/ (1970), 84-106. https://doi.org/10.2307/750892

İmam-1 Kastalâni. Gönül Nimetleri El-Mevahib-ül Ledûniyye. çev. Necip Fazıl Kısakürek, 1996.

İnal, Güner. "Artistic Relationship Between The Far And The Near East As Reflected in The Miniatures Of The Jāmi 'AtTawārīh". Kunst des Orients 10/1/2 (1975), 108-143. https://www.jstor.org/stable/20752459

İnal, Güner. "Some Miniatures of the 'Jāmi' al-Tav Ārīkh' in Istanbul, Topkapi Museum, Hazine Library No. 1654". Ars Orientalis 5/ (1963), 163-175. https://www.jstor.org/stable/4629187

İnal, Güner. Türk Minyatür Sanatı (Başlangıcından Osmanlılara Kadar). Ankara, 1976.

Jahn, Karl. "Cihan Tarihçisi Olarak Reşidüddin". İslam Tetkikleri Dergisi 3/ (1966), 227-236. https://dergipark.org.tr/tr/pub/iuislamtd/13995

Jahn, Karl. "The still missing works of Rashīd al-Dīn”. Central Asiatic Journal, 113-122.

Kazdhan, Alexander. "Vatopedi Monastery". The Oxford Dictonary of Byzantium. 2155, Oxford: Oxford University Press, 1991.

Kitzinger, Ernst. "The Mosaics of the Cappella Palatina in Palermo: An Essay on the Choice and Arrangement of Subjects". The Art Bulletin 31/4 (1949), 269-292. https://doi.org/10.2307/3047256

Koc, Turan. İslâm Estetiği. Ankara: İSAM Yayınları, 2018.

Koçyiğit, Fazilet, “Tağar (St. Theodore) Kilisesi Duvar Resimleri”. Erciyes Üniversitesi Sosyal Bilimler Enstitüsü Dergisi $1 / 26$ (2009), 35-59.

Koçyiğit, Talat. "Abdullah b. Übey b. Selûl”. TDV İslam Ansiklopedisi. 139-140. Ankara: TDV Yayınları, 1988.

Köksal, Mustafa Asım. İslâm Tarihi Hz. Muhammed (As.) ve İslâmiyet, İstanbul: Şamil Yayınevi, 1981.

Maguire, Henry, "Kariye Camii Sanatında Retorik ve Gerçeklik", çev. İnci Türkoğlu, Kariye Camii Yeniden - The Kariye Camii Reconsidered, ed. Holger A. Clein v.d. 37-69. İstanbul: İstanbul Araştırmaları Enstitüsü, 2011.

Michaelis, Wilhelm. Die Apokryphen Schriften zum Neuen Testament. Bremen, 1958.

Ousterhout, Robert G. Visualizing Community, Art, Material Culture and Settlement in Byzantine Cappadocia. Washington: Sheridan Books, 2017.

Önkal, Ahmet. "Akabe Biatları”. TDV İslam Ansiklopedisi. 211. Ankara: TDV Yayınları, 1989.

Özgüdenli, Osman Gazi. "Bir İlhânlı Şehir Modeli: Rab-1 Reşî̀ı̂'de Meslekler, Görevliler ve Ücretler”. Osmanlı Öncesi İle Osmanlı ve Cumhuriyet Dönemlerinde Esnaf ve Ekonomi Semineri, 105-127.

Özgüdenli, Osman Gazi. "Reşîdüddin Fazlullâh-1 Hemedânî”. TDV İslam Ansiklopedisi. 35/19-21. Ankara: TDV Yayınları, 2008.

Özgüdenli, Osman Gazi. “Tarih”. TDV İslam Ansiklopedisi. 54-58. Ankara: TDV Yayınları, 2011.

Özkuyumcu, Nadir. "Nâdir”. TDV İslam Ansiklopedisi. 275-276. Ankara: TDV Yayınları, 2006.

Panofsky, Erwin. İkonoloji Araştırmalar. çev. Orhan Düz. İstanbul: Pinhan Yayıncılık, 2012.

Pantazis, GEORGE - Papathanassiou, MARIA. "On the date of the Katholikon of Daphni monastery. A new approach based on its orientation". Mediterranean Archaeology and Archaeometry 5/1 (2005), 63-72.

Pekak, M. Sacit - Durmuş, GÜR. “İsa’nın doğumu”. Sanat Tarihi Dergisi 24/2 (2015), 175-226.

Raşîd Al-Dîn Fazlallâh. Câmi' Al-Tavârîh. (Haz. Ahmed Ateş), Ankara: TTK, 1999.

Sach, Hannelore vd. Christliche Ikonographie in Stichworten. Leipzig: Koehler \& Amelang, 1988.

Sarıkçıoğlu, Ekrem. Diğer İnciller (Apokrif İnciller). İstanbul: Fakülte Kitabevi, 2009.

Serdar Dinçer, Pınar. "Erken Bizans Dönemi Resimli Dini El Yazmaları". Art-Sanat 19 (2019), 385-420.

Smith, Earl Baldwin. Early Christian Iconography and A School of Ivory Carves in Provence. Princeton, 1918. 
Süleyman Çelebi. Mevlid (Vesiletü'n-Necat). (Haz. Faruk Timurtaş), İstanbul, 1980.

Süleyman Çelebi. Mevlid (Vesiletü'n-Necat). (Çev. Necla Pekolcay), İstanbul, 1992.

Şeşen, Ramazan. "Câmiu’t-Tevârîh". TDV İslam Ansiklopedisi. 132-134. Ankara: TDV Yayınları, 1993.

Topaloğlu, Bekir. "Âmine”. TDV İslam Ansiklopedisi. 170-174. Ankara: TDV Yayınları, 1991.

Tükel, Uşun - Yüzgüller Arsal, Serap. Sözden İmgeye Batı Sanatında İkonografi. İstanbul: Kabalcı Yayınları, 2014.

Wilber, Donald N. - Minovi, Mojtaba. "Notes On The Rab'-1-Rashidi”. Bulletin of the American Institute for Iranian Art and Archaeology 5/3 (1938), 246-254.

Yörük, Özge. Bizans Sanatında Doğum Sahnelerinin İkonografik Çözümlenmesi. Konya: Selçuk Üniversitesi, Sosyal Bilimler Enstitüsü, Yüksek Lisans Tezi, 2016.

Britannica, "San Marco Basilica", Erişim 1 Şubat 2020. https://www.britannica.com/place/Venice/Cultural-heritage-themyth-of-Venice\#ref388655)

British Library, "Bristol Psalter", (Erişim 1 Şubat 2020). https://www.bl.uk/collection-items/the-bristol-psalter.

Edinburgh Üniversitesi, "Jāmi" al-tawārīkh (Compendium of Chronicles by Rashid al-Din), 714 A.H. (1314 C.E.)" (Erişim 7 Haziran 2021). https://archives.collections.ed.ac.uk/repositories/2/archival_objects/145535.

Khalili Collection, "Jāmi" al-tawārīkh MSS 727", $\quad$ (Erişim 7 Haziran 2021$)$. https://www.khalilicollections.org/collections/İslamîc-art/khalili-collection-İslamîc-art-the-jami-al-tawarikh-ofrashid-al-din-mss727-folio-11a/

Özkan, Mustafa. “Medine Vesikası”,TDV İslam Ansiklopedisi, Erişim 31 Ocak 2020 https://islamansiklopedisi.org.tr/medinevesikasi

Scala Archives, "Entry of Jesus into Jerusalem", Erişim $15 \quad$ Haziran 2021. http://www.scalarchives.com/web/dettaglio immagine.asp?idImmagine=0009543\&posizione=4\&inCarrello=False \&numImmagini $=11 \&$

Wissenschaftliche Bibliothek der Stadt Trier, "Der-Egbert-Codex”, Erişim 23 Mart 2020. http://www.stadtbibliothekweberbach.de/icc/stadtarchiv/nav/5df/5df7097f-92c8-6e31-fc8e-9a153d761716\&sel uCon=a1a60db6-f644-6e31bba5-7ac63d761716\&uTem=63f7089a-29fc-6c31-e777-d8b132ead2aa.htm

Work of God, "The Gospel Of The Nativity Of Mary", Erişim 21 Şubat 2020. https://www.theworkofgod.org/Aparitns/PevglJms.htm\#THE\%20GOSPEL\%20OF\%20THE\%20NATIVITY\%20O F\%20MARY

\section{GÖRSELLER}

Wikimedia Commons, "Mohammed receiving the submission of the Banu Nadir", Erişim 10 Kasım 2021. https://upload.wikimedia.org/wikipedia/commons/f/f8/Mohammed_receiving_the_submission_of_the_Banu_Nadir. jpg

Wikimedia Commons, "Kariye Camii, Birth of the Virgin Mosaic, Istanbul, Turkey", Erişim 10 Kasım 2021. https://commons.wikimedia.org/wiki/File:Kariye_Camii,_Birth_of_the_Virgin_Mosaic,_Istanbul,_Turkey__Preparation_of_the_bath,_midwife_and_attendant_bathing_infant_Mary_-_MSBZ004-ICFA-KC-BIA-0270_Dumbarton Oaks.jpg

$\begin{array}{lllllll}\text { Wikimedia } & \text { Kommons, } & \text { Kilise", } & \text { Erişim } & 7 & \text { Kasım } & 2021 .\end{array}$ https://upload.wikimedia.org/wikipedia/commons/thumb/9/9b/Tokali_kilise.jpg/1600px-Tokali_kilise.jpg

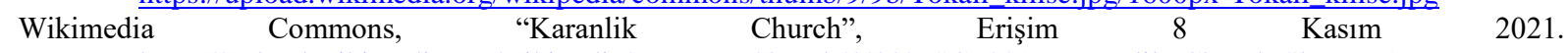
https://upload.wikimedia.org/wikipedia/commons/thumb/4/44/DSCF0817-Karanlik_Church-SharpenAIstabilize.jpg/1600px-DSCF0817-Karanlik_Church-SharpenAI-stabilize.jpg

The Met Museum, "The Fieschi Morgan $\begin{array}{llllll}\text { Staurotheke", } & \text { Erişim } & 9 & \text { Kasım } & 2021 .\end{array}$ https://collectionapi.metmuseum.org/api/collection/v1/iiif/472562/959529/main-image

Louvre Museum, “Triptyque: la Nativité”, Erişim 9 Kasım 2021. https://collections.louvre.fr/en/ark:/53355/c1010113301

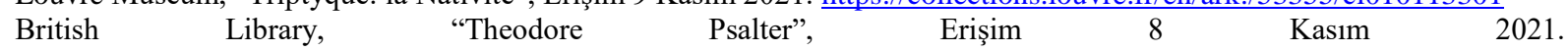
http://www.bl.uk/manuscripts/Viewer.aspx?ref=add_ms_19352_f001r

Wikimedia Commons, “Annunciation Icon Sinai 12th century”, Erişim $7 \quad$ Kasım 2021. https://upload.wikimedia.org/wikipedia/commons/8/82/Annunciation_Icon_Sinai_12th_century.jpg

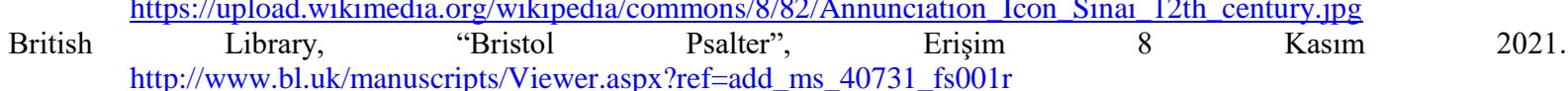

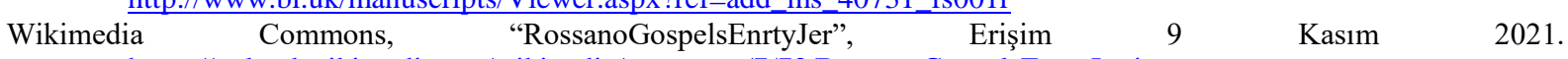
https://upload.wikimedia.org/wikipedia/commons/7/73/RossanoGospelsEnrtyJer.jpg

Wikimedia Commons, "Meister der Palastkapelle in Palermo", Erişim 9 Kasım 2021. https://upload.wikimedia.org/wikipedia/commons/thumb/3/30/Meister_der_Palastkapelle_in_Palermo_002.jpg/158 4px-Meister_der_Palastkapelle_in_Palermo_002.jpg

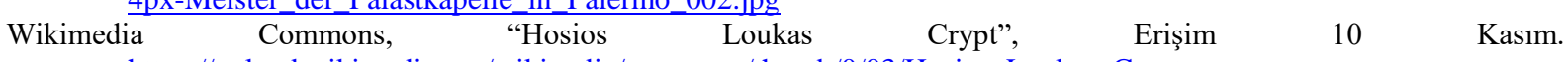
https://upload.wikimedia.org/wikipedia/commons/thumb/0/03/Hosios_Loukas_Crypt__Entry_into_Jerusalem_01.jpg/1509px-Hosios_Loukas_Crypt___Entry_into_Jerusalem_01.jpg 